\title{
THE TERM STRUCURE OF INTEREST RATE IN A SFC MODEL WITH INFLATION TARGETING AND ZERO MONEY FINANCING OF GOVERNMENT DEFICIT
}

\author{
A ESTRUTURA A TERMO DA TAXA DE JUROS E A DISTRIBUIÇÃO DE RENDA NUM \\ MODELO PÓS-KEYNESIANO DE CONSISTÊNCIA ENTRE ESTOQUES E FLUXOS \\ COM METAS DE INFLAÇÃO E FINANCIAMENTO NÃO-MONETÁRIO DO DÉFICIT \\ PÚBLICO
}

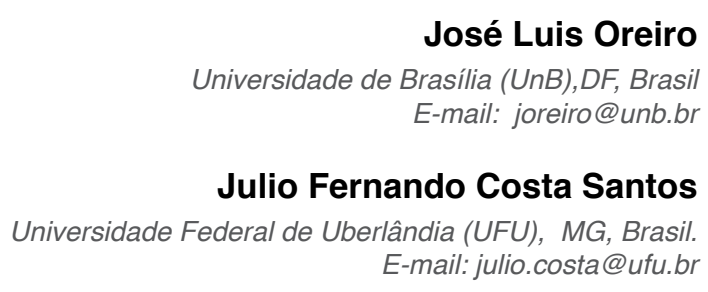

Recebido em: 07.08.2020 - Aceito em: 28.08.2020

DOI: http://dx.doi.org/10.5902/2526629263702

ABSTRACT: The aim of the present paper is to build an SFC Post-Keynesian growth model for a closed economy with government activities that incorporates the Institutional Arrangement of fiscal and monetary policy that exists in many countries of the real world. More precisely in our model monetary policy will be conducted under the framework of Inflation Targeting Regime, direct money financing of government deficit will be forbidden by law and government issued interest rate-indexed bonds in order to finance its fiscal deficit. Hence the model is used to analyze the effects of a once-and-for all change in the level of government expenditures over the time path of investment to GDP ratio, profit share, capacity utilization, the spread between long-term and short-term interest rates and inflation. The results of the simulation show that a permanent increase in the level of government expenditures is followed by a permanent decrease in the investment to GDP ratio, a permanent increase in the spread between long and short-term interest rate, a permanent decrease in the level of capacity utilization and a permanent increase in the profit share, but with no lasting effects over inflation dynamics.

Keywords: Stock-Flow Consistency Model; Conflict Claims; Financialization; Taylor Rule, Term Structure of Interest Rates.

RESUMO: O objetivo do presente artigo é construir um modelo de crescimento pós-keynesiano tipo SFC para uma economia fechada com atividades 
governamentais que incorpore o Arranjo Institucional da política fiscal e monetária que existe em muitos países do mundo real. Mais precisamente em nosso modelo de política monetária será conduzida sob o arcabouço do Regime de Metas de Inflação, o financiamento direto do déficit público será proibido por lei e o governo emite títulos indexados à taxa de juros para financiar seu déficit fiscal. Assim, o modelo é usado para analisar os efeitos de uma mudança permanente no nível de gastos do governo sobre a trajetória de taxa de investimento, participação dos lucros na renda, utilização da capacidade, spread entre taxas de juros de longo e curto prazo e inflação. Os resultados da simulação mostram que um aumento permanente do nível de gastos públicos é seguido de uma redução permanente da relação investimento/PIB, um aumento permanente do spread entre a taxa de juros de longo e curto prazo, uma redução permanente no nível de utilização da capacidade e um aumento permanente da participação dos lucros na renda, mas sem efeitos persistentes sobre a dinâmica da inflação.

Palavras-chave: Modelo de Consistência entre Fluxos e Estoques; Conflito Distributivo; Financeirização; Regra de Taylor, Estrutura a Termo das Taxas de Juros.

\section{INTRODUCTION}

Two major theoretical postulates of Keynesian economics are that the level of interest rate is a strict monetary phenomenon, being determined by the interaction between liquidity preference of households, firms and commercial banks and the monetary policy conducted by Central Bank (Carvalho, 2015, pp.21-25); and that an increase in government (or other element of the so-called autonomous) expenditures will always increase the level of output and employment and hence aggregate savings, avoiding a crowding out of private investment by government expenditures due to a "lack of savings" (Amadeo, 1989, pp.113-117), at least if the economy is operating in a situation of underemployment equilibrium 1 . The first postulate is the Liquidity Preference Theory, the second is the Principle of Effective Demand.

These postulates are generally presented in a very simplified model about the workings of the economic system, where there is just one interest rate and the stock-flow implications of financing of government deficits are ignored. Many years ago, the dependence of these postulates on simplified assumptions regarding the structure of economic system were questioned by Tom Asimakopoulos, an

$1 \quad$ The idea that output is demand determined is also valid in the long-run is due to Kaldor (1988). 
unsuspected Keynesian economist. In his 1991 book, Asimakopoulos said that "Keynes's theory of interest is dependent on the long-term expectations that determine the position and shape of liquidity preference function. He did not recognize that these long-term expectations could be affected by comparison of projected rates on investment and projected savings (based on economy's propensity to save) in future periods. If it appears that investment would be greater than normal savings, concerns over future interest rates could bring about immediate increases in long-term rates that act as a damper to investment plans. Thus, the independence of investment from saving - a key element in Keynes's theory - does not hold in all circumstances" (Asimakopoulos, 1991, p.116).

The development of the so-called stock-flow consistent models by Godley (1999), Lavoie and Godley (2001), Zezza and Dos Santos (2006), Godley and Lavoie (2007a, 2007b) and Dos Santos and Zezza (2008) allowed the construction of a series of macroeconomic models that could track the stock-flow implications of financing of government deficit over the whole term structure of interest rates. One of such models is the one presented in chapter five of Godley and Lavoie (2007b). These authors considered a closed economy with four economic sectors: households, firms, government and central bank. Households' wealth is stored in three types of assets, that are imperfect substitutes one to the other: money, bills and bonds. Bills are the short-term debt issued by the central bank in order to regulate the balance sheet liquidity of the private sector. Since bills are short-term debt, they are not exposed to the risk of capital losses. Bonds are the long-term debt issued by the government in order to finance its fiscal deficit. Long-term bonds are constituted by perpetuities, whose market price is an inverse function of the long-term interest rate (Godley and Lavoie, 2007b, p.132). These means that capital gains or losses must be taken explicit in consideration in the Transaction Flow Matrix of the model (Ibid, p. 138). Long term bonds are sold in capital markets, but central bank act as a buyer of last resort, buying all bonds that are not bought by households (Ibid, p. 166). This means that monetary financing of government deficits is allowed by the Institutional Arrangement of fiscal and monetary policy.

Their model presented some counter-intuitive results. For example, the yield curve will assume a negative slope as a result of once and for all increase in the short-term interest rate (p.156). Also, in the LP3 closure of the model, where government expenditures are made endogenous by means of the introduction of a reaction function for government expenditures that is dependent on the ratio of public sector borrowing requirement to GDP (p.161); a sharp decrease in the pro- 
pensity to consume out of disposable income will produce a permanent reduction on the level of GDP. This result occurs due to the fact that a reduction in private consumption expenditure triggers also a reduction of government expenditures, due to effect of the fall in economic activity over the tax receipts and hence over the ratio of public sector borrowing requirement to GDP, generating a strange "crowding-in" effect. Besides this monetary policy is completely exogenous, since shortterm interest rate is set at a level that is not related to any of the traditional goals of monetary policy, like to achieve some target inflation or to eliminate the output gap.

The great shortcoming of the Godley and Lavoie (2007b) model, however, is the lack of correspondence between Institutional Arrangement of fiscal and monetary policy assumed by the model and the one that prevails in the real world. In many developed and developing economies monetary policy is operated under the framework of Inflation Targeting Regimes, which reduces enormously the scope for monetary authorities to set "freely" the level of short-term interest rates. Moreover, in many countries money financing of government deficits is explicitly forbidden by law. This is, for instance, the case of Brazil, where loans of central bank to the treasury are explicitly forbidden by the article 164 of the Federal Constitution? Moreover, perpetuities are not the main type of bonds issued by government in order to finance its fiscal deficit. Taking again Brazil as an example, more or less $40 \%$ of government debt is constituted by the so-called Financial Treasury Bills (Letras Financeiras do Tesouro) which is an interest rate-indexed bond that had a special feature of having zero duration in Mackaulay sense ${ }^{3}$, which means that the price of these bonds has no sensitivity to changes in interest rates ${ }^{4}$, being free of the risk of capital losses, whatever their maturity (Holanda Barbosa, 2006).

The aim of the present article is precisely to build an SFC growth model that incorporates some features of the Institutional Arrangement of fiscal and monetary policy that exists in the real world. More precisely in our model monetary policy will be conducted under the framework of Inflation Targeting Regime, money financing of government deficit will be -forbidden by law and government issued interest rate-indexed bonds in order to finance its fiscal deficit. It is important to notice that our goal is not to present a model that can be directly applied to any advanced or developing economy, but a more modest one: to analyze the implications of some "stylized facts" regarding the Institutional Arrangement of fiscal and monetary pol-

2 See https://www.senado.leg.br/atividade/const/con1988/con1988_14.12.2017/art_164_.asp.

$3 \quad$ About duration in Mackaulay sense see Fabozzi (1999)

$4 \quad$ One important implication of this kind of bond for the construction of SFC models is that there are no capital gains or losses on long-term bonds to be included in the Transaction Flow Matrix of the Model. 
icy over the dynamics of an artificial economy 5 . Moreover, we are not saying that these institutional arrangements should be considered the ideal one for the conduction of fiscal and monetary policy; but we only want to analyze its effects over the dynamics of our artificial economy since these arrangements are the ones that prevails in many countries in the real world ${ }^{6}$.

In the model to be presented in this paper we will consider a closed economy with government activities. Firms produces a homogeneous output, which served both for consumption and investment; and operate in a market structure characterized by monopolistic competition. Prices are set by means of a variable mark-up rate over unit labor costs. Labor is the only variable input used in production, but production also requires the utilization of physical capital. Regarding pricing decisions, we will consider that the interest on loans as one of the main determinants of mark-up rate. This assumption expresses the idea that our model economy works in in accordance to the logic of the actual stage of the capitalist evolution, which is the finance-dominated capitalism (Hein, 2012). On this stage of capitalist evolution, the financial variables had a growing influence over the production, pricing and investment decisions of productive firms ${ }^{7}$.

Government takes no production activities and buys goods from firms in order to carry on its (unproductive) activities. Government consumption is financed by income taxes and by selling interest rate-indexed bonds to the rentiers. All investment is made by private firms and is financed by retained profits and loans from commercial banks. Workers are organized in labor unions in order to strength their position in the wage bargains. Labor unions define targets for the wage share in income, based on which they set the rate of wage inflation.

Central Bank operates monetary policy in an Inflation Targeting Regime, setting the short-term interest rate in order to achieve a numerical target for inflation rate in the long-term. Central bank is forbidden by law to buy government bills, so there is no fiscal dominance and government had to finance $100 \%$ of fiscal deficit by selling interest rate-indexed bonds on capital markets. This means that long term interest rate is thus determined by capital markets, being the price that coordinates the portfolio decisions of households from one hand, and the composition

5 Shumpeter (1954) called the direct application of economic theory to policymaking by the term "Ricardian vice". The vice consists in ignoring the differences between pure economics, that deals with the logical of the phenomenon, and the art of economics that requires a direct knowledge of the specificities which characterize the time-space individuality of any economy (Silveira, 1992). Our model should be evaluated as a contribution to the logic of the phenomenon, not as a description of the actual workings of any individual economy. $6 \quad$ Regarding the possible compatibility of Inflation Targeting and Post Keynesian Economics see Setterfield (2006) and Lima and Setterfield (2008).

$7 \quad$ For s formal treatment of "financialization" in SFC models see Trreck (2009). 
of financial wealth from the other side. Government bills are assumed to be free of interest risk since coupon payments are indexed by the long-term rate. Due to the institutional constraints regarding money financing of public debt, Central Bank had to conduct monetary policy by setting the interest rate on loans to the banking sector, without the use of the so-called "open market operations". Households are composed by workers and rentiers. Workers are supposed to "spend all they get" in consumption goods; and rentiers save all their current income - originated from distributed profits and interest on bonds - and store it in financial assets. All financial wealth belongs to rentiers.

Once the accounting structure and the behavior equations of the model are presented and explained, then we will use an algorithm developed by Costa Santos $(2017)^{9}$ in order to find the parameters for the model that generate steady-state values for the endogenous variables. In the baseline model dynamics, the economy will converge to a steady-state position where (i) long-term interest rate is higher than short term interest rate, defining a yield curve with positive inclination; (ii) both demand and accumulation regimes are wage-led; (iii) inflation rate converges to the target; and (iv) government to GDP ratio stabilized at a considerably low level.

Hence the model is used to analyze the effects of a once-and-for all change in the level of government expenditures over the time path of investment to GDP ratio, profit share, capacity utilization, the spread between long-term and shortterm interest rates and inflation. The results of the simulation show that a permanent increase in the level of government expenditures is followed by a permanent decrease in the investment to GDP ratio, a permanent increase in the spread between long and short-term interest rate, a permanent decrease in the level of capacity utilization and a permanent increase in the profit share, but with no lasting effects over inflation dynamics.

These results show that in an SFC growth model with inflation targeting and zero money financing of fiscal deficit, a permanent increase in the level of government expenditures produces a crowding-out effect over investment expenditures and a redistribution of income from households to firms and rentiers. This is a novel and surprising result for the SFC model literature.

\footnotetext{
$8 \quad$ Although in Brazil Central Bank cannot buy public bonds on primary markets, the bonds required for the conduction of monetary policy through Repurchasing Agreements Operations (REPO) are "given" by Treasury to the Central Bank and booked as an increase in the net worth of the Central Bank. This means that when Brazilian Central Bank needs more bonds to sell to the market in order to keep the short-term interest rate at the level required to achieve the target inflation, Treasury had to issue bonds and make a capital injection to the Central Bank, increasing its net worth. It is important to notice that this operation has no direct impact over monetary base, which means that it is not, strictly speaking, money financing of fiscal deficit.

9 In that work, Costa Santos (2017) shows that there are similar results between studying the stability criterion by the traditional analytical method and the algorithm developed for model simulation.
} 


\section{INFLATION TARGETING AND FISCAL POLICY IN POST KEYNESIAN TRA- DITION AND SFC MODELS}

The SFC approach has its origin in the works of Tobin (e.g. 1980, 1982) and developed by Godley and Cripps (1983), Godley (1996, 1999), Lavoie and Godley (2001) and synthesized in the book "Monetary Economics: An Integrated Approach to Credit, Money, Income, Production and Wealth" by Godley and Lavoie (2007b). The main characteristic of this macroeconomic approach is to respect a strictly defined accounting structure, so that the models incorporate the existing relationships in the balance sheets, income and funds flows between the sectors in the modeled economy. Thus, we have the general principle defined by Godley and Lavoie (2007b) who states that:

\footnotetext{
"Our method is rooted in the fact that every transaction by one sector implies an equivalent transaction by another sector (every purchase implies a sale), while every financial balance (the difference between a sector's income and its outlays) must give rise to an equivalent change in the sum of its balance-sheet (or stock) variables, with every financial asset owned by one sector having a counterpart liability owed by some other. Provided all the sectoral transactions are fully articulated so that 'everything comes from somewhere and everything goes somewhere' [...]" (Godley e Lavoie, 2007b, p. xxxiv).
}

A highlight point is that these models are created inspired by portraying modern industrial economies, which have a complex institutional structure that includes the existence of firms, banks, governments and households, in which the evolution over time depends on the way in which decisions within and between existing sectors.

More strictly in the SFC literature, there are few studies involving fiscal policy and inflationary dynamics. As main references, we have: Godley and Lavoie (2007a and 2007b); Le Heron (2008; 2012) and Greenwood-Nimmo (2013).

The first reference is an extension of the model proposed in the book by Godley and Lavoie (2007, chap. 11). In the paper also written in 2007, the authors states that:

“...monetary policy on its own was unable to maintain full employment and low inflation for more than a short period of time, unless fiscal policy was appropriate. Our conclusions conflict with those of the "new consensus," which holds that a correct setting of interest rates is the necessary and sufficient condition for achieving noninflationary growth at full employment, leaving fiscal policy rather in the air". (Godley and Lavoie, p. $79,2007 b)$ 
The authors throughout the article point out that the power of fiscal policy in being a stabilization tool is similar to that of monetary policy, although they know that for policy making, fiscal policy is much rustier and slower. In the words of the authors: "In theory, although in practice this may be an entirely different issue, fiscal policy can achieve everything the central banks claim they are able to do through monetary policy".

Regarding the model developed, there is a division of two parts. The first, in a simplified version that exogenously defines the rate of inflation as well as the pace of economic growth. Having this framework, the simulations indicate that:

\begin{abstract}
"It is usually asserted that, for the debt dynamics to remain sustainable, the real rate of interest must be lower than the real rate of growth of the economy for a given ratio of primary budget surplus to GDP. If this condition is not fulfilled, the government needs to pursue a discretionary policy that aims to achieve a sufficiently large primary surplus. We can easily demonstrate that there are no such requirements in a fully consistent stock-flow model such as ours. ... The model yields stable, nonexplosive, results. ... It makes no sense to put limits on deficit or debt ratios, as in the Maastricht rules and Gordon Brown's golden rules, outside the context of how any economy actually works." (Godley and Lavoie, p. 87, 2007b)
\end{abstract}

The results obtained from the first part of the model are considered to be unconventional. These bring an important point to the discussion about recommended public debt levels, as well as about the possibility of the interest rate being higher than the growth rate of the economy ${ }^{10}$. However, the model has little or nothing to say about the inflation-generating process.

In the second part of the article, the simple version of the model is modified to endogenize the inflation rate in order to generate a vertical Phillips Curve and the growth rate of (real) public spending is also endogenized as a way of creating an active fiscal policy and synchronized with the inflation target. In making use of this specification, the authors show that:

“...That an economy (described within an SFC framework) with a real rate of interest net of taxes that exceeds the real growth rate will not necessarily generate explosive interest flows, even if the government makes no discretionary attempt to achieve primary budget surpluses, and, second, that it cannot be assumed that a debtor country requires a trade surplus if interest payments on debt are not to explode". (Godley and Lavoie, p. 99, 2007b)

An important discussion about experiments involving monetary policy and 10 An explanation of the non-consensual term is here. The usual idea would be to invalidate the possibil-
ity of the interest rate being higher than the growth rate of the economy in the Long Term. 
fiscal policy in an SFC approach was written by Le Heron (2012). In this chapter of the book, the author recounts his contact with W. Godley in 2006 and an important question was raised in this dialogue:

"Therefore, how could one measure the real impact of monetary policy, given that fiscal policy would react to mitigate this impact? My question was: how to neutralize fiscal policy with the aim of measuring only the effects of monetary policy?" (Le Heron, Ch. 9, p. 267. In Papadimitriou and Zezza, 2012).

To answer this non-trivial question, there is a survey of six main hypotheses. The first $(\mathrm{H} 1)$ does not change anything. Maintain the same action of the fiscal policy after the shock. Here, there is no coordination between the performance of the Central Bank and the fiscal policy. In this case, fiscal policy is neither neutral nor neutralized, since it remains counter-cyclical. The second and third hypothesis $(\mathrm{H} 2$ and $\mathrm{H} 3)$ create targets for fiscal deficits and debts. The first deals with the flow and the second with the stock trying to stabilize them after the shock. The fourth hypothesis (H4), entitled Godley's proposal, is the fiscal policy of maintaining constant the growth rate of public spending during the shock of monetary policy, thus becoming exogenous. It would be something like a passive fiscal policy.

Lastly, we have the fifth hypothesis (H5), corresponding to Ricardian equivalence and the sixth hypothesis $(\mathrm{H} 6)$ representing the treasury view with the aim of keeping the budget balanced. The structure of this model uses the view of the endogenous money, fixing the interest rate exogenously and therefore fully accommodating the demand of liquidity by banks through advances. As a conclusion, the author points out that:

"...monetary and fiscal policies seeking to find a certain rate of economic growth usually compatible with full employment. Neutrality must be understood in terms of general economic policy and not at the level of one policy. Post-Keynesians believe that fiscal policy is always active; to measure only the effects of monetary policy is simply an illusion. With the proposal of Wynne Godley, fiscal policy neutralizes the impact of monetary policy. Fiscal policy is counter-cyclical and can be considered neutral because it corresponds nor to acceleration, neither to slowdown in growth. Wynne Godley's proposal is the best post-Keynesian answer". (Le Heron, Ch. 9, p. 267. In Papadimitriou and Zezza, 2012).

A more recent article developed by Greenwood-Nimmo (2013) inspired by the SFC structure of Godley and Lavoie (2007A and 2007B, Chap. 7) brought the discussion of the introduction of inflation targets for a two-country open economy. The author argues that there is a great limitation in using models in a closed econ- 
omy, due to the transmission channels between the domestic interest rate, the exchange rate and inflation. In addition, the same work argues that the use of uncovered interest parity, typically used in orthodox models, only allows the investigation of cases where the local economy is too small compared to the rest of the world.

In this sense, the author uses a two-country model (in order to endogenize the channels), modeling an inflationary dynamic via distributive conflict and creates endogenous cycles in the GDP so as to activate stabilization policies through the Central Bank. Regarding this last issue, the author makes the propensities to consume out of income and wealth to be functions of the real interest rate.

Continuing, some specifications of fiscal and monetary policy functions are introduced to test the stabilization results. Among them, can be highlighted: (i) a simple IT rule; (ii) a modified IT rule where $C B$ of country $B$ reacts to the interest rate set by $\mathrm{CB}$ of country $\mathrm{A}$; (iii) a combination of (i) with counter-cyclical fiscal policy; and (iv) a combination of (ii) with counter-cyclical fiscal policy.

Finally, the paper concludes that neither fiscal policy nor monetary policy, in isolation, can have full potential to stabilize the model. The combination of both generates a much more effective response. In addition, excesses of reaction by the monetary authority cause an increase in the equilibrium interest rate. Nevertheless, the IT policy raises the exchange rate volatility in the model.

Thus, we have that the current literature on SFC models that bring the discussion about fiscal policy and inflation targets is still embryonic. There are reasonable contributions about fiscal policy as a tool for price stabilization, but without bringing institutional issues into the model. Similarly, there are initial results in the same literature for the effects of monetary policy involving IT.

In the current article, we will expand the discussion by considering the interaction of two stylized facts, namely: (1) The prohibition of treasury financing by the Central Bank and (2) The inflation targeting regime. In this choice, we use a model inspired by Dos Santos and Zezza (2008) that allows a greater degree of understanding of the channels (as it is a model closer to analytical resolution or reduction in the number of equations). Further details of the model are made in sections 3 and 4.

\section{ACCOUNTING STRUCTURE AND ASSUMPTIONS OF THE MODEL}

As we had told in the introduction, the model at hand aims to understand the dynamics of public financing and its interrelations with the other macroeconomic variables in a closed economy adopting as hypothesis the non-financing of long- 
term public debt securities through the Central Bank (an unusual hypothesis in the SFC literature, but it is a good representation of the relation of monetary and fiscal authorities in some countries as, for example, Brazil). As a starting point, we will describe the basic structural features of this economy.

First, we will consider an economy with unlimited labor supply during simulated periods, so that the availability of labor is never a constraint to the expansion of output (Lewis, 1954). The existence of labor unions, however, makes it possible for wages of employed workers to be set above the subsistence level due to the insider-outsider effect in wage bargaining (Blanchard and Fischer, 1989, pp. 448-449). In other words, only employed workers participate in the wage bargaining. There is also no technical progress which guarantees a constant level of labor productivity.

The model assumes the existence of five institutional sectors: households (workers and rentiers), firms, commercial banks, central bank and government. Aligned to the most common hypothesis in SFC models, this is a one-good economy, where output can be both invested and consumed. Table 1 and table 2 summarize the accounting structure of this economy, representing the assets and liabilities of the institutional sectors and the matrix of transactions and flow of funds, respectively.

Regarding households, we will adopt the traditional Post-Keynesian hypothesis of class segmentation between workers and rentiers (Harcourt, 2006, pp. 6-11). The first group receives wages from their labor supply and spends them paying taxes over their income and consuming everything else. In this way, since there are no leftovers (no savings) and there is no wealth inherited by this class. Their equity is zero and workers do not accumulate wealth over time.

The second class is formed by the rentiers. This class do not supply labor services and their income comes from distributed profits from firms and banks and interests over financial wealth. Rentiers' financial wealth is allocated between bank deposits and interest rate-indexed government bonds. These two assets generate as gross income interest on deposits and interest on bonds. Over this interest income, rentiers had to pay a tax rate, making net interests smaller than gross interests. Since we are considering interest rate-indexed government bonds, there is no capital gains or losses to be computed as part of the disposable income of rentiers.

The firms, in turn, havein their balance sheet the physical capital responsible for production of goods supplied in this economy. On the liability side, there are loans taken from commercial banks.

Government had only interest rate-indexed bonds as its' liabilities. Therefore, it is also assumed that government do not undertake any production activities. Government net worth is also negative. The Central Bank (CB) is not allowed 
by law to buy bonds, so there is a clear institutional separation between fiscal (Treasury) and monetary (Central Bank) authorities ${ }^{11}$. CB's liability is made up of the reserves of the Banking Sector, since there is no paper money in the system; and the asset side is constituted by the advances provided to the banking system to guarantee its liquidity. The only relation that arises in this economy between the $\mathrm{CB}$ and the Government is that the profit obtained by the receipt of interest from the banks due the advances is distributed to the Treasury.

Lastly, we have commercial banks that have as assets the loans granted to firms and reserves within $\mathrm{CB}$. On the liability side, loans taken via advances with $\mathrm{CB}$ and the deposits of the rentiers. The commercial bank profit comes from the spread between the interest rate of funding and the interest rate of the loans provided to the firms.

Table 1 - Balance Sheet of the SFC Model

\begin{tabular}{|c|c|c|c|c|c|c|c|}
\hline & Workers & Firms & Government & Banks & Central Bank & Rentiers & $\Sigma$ \\
\hline Loans & & $-L$ & & $+L$ & & & 0 \\
\hline Bank Deposits & & & & $-D$ & & $+D$ & 0 \\
\hline Bank Reserves & & & & $+R$ & $-R$ & & 0 \\
\hline CB Advances & & & & $-A$ & $+A$ & & 0 \\
\hline Bonds & & & $-B$ & & & $+B$ & 0 \\
\hline Fixed Capital & & $+p . K$ & & & & & $+p \cdot K$ \\
\hline Balance (Net Worth) & 0 & $-V_{f}$ & $-V_{0}$ & $-V_{b}$ & $-V_{c b}$ & $-V_{r}$ & $+p . K$ \\
\hline$\underline{\Sigma}$ & 0 & 0 & 0 & 0 & 0 & 0 & 0 \\
\hline
\end{tabular}

Note: Positive sign (+) preceding a variable represents an asset for that agent and negative sign (-) represents a liability.

11 Regarding the issue of the separation of fiscal and monetary authorities, Lavoie (2019), in his criticism to Modern Money Theory, says that "(...) the consolidation of the central bank and the government into a single entity should enter the policy debate though institutional change, and not as an actual feature of the economy upon which policy advice should be offered" (p.105). In this paper, however, Lavoie argues that "it really does not matter whether the central bank was purchasing government securities on the primary or secondary markets" (p.104). In the model presented here the prohibition of money financing of fiscal deficit - that is, the prohibition of central bank to buy government bonds in primary markets - matter for the dynamics of the model economy. 
Table 2 - Transactions-Flow Matrix of the SFC Model.

\begin{tabular}{|c|c|c|c|c|c|c|c|c|}
\hline & \multirow[b]{2}{*}{ Workers } & \multicolumn{2}{|c|}{ Frms } & \multirow[b]{2}{*}{ Gxartment } & \multirow[b]{2}{*}{ Central Bank } & \multirow[b]{2}{*}{ Bunks } & \multirow[b]{2}{*}{ Renticys } & \multirow[b]{2}{*}{$\varepsilon$} \\
\hline & & Curnent & Cppial & & & & & \\
\hline Consumpoina & $-C_{W}$ & $+c$ & & & & & $-C_{R}$ & 0 \\
\hline Imestment & & +1 & -1 & & & & & 0 \\
\hline Gonernment Expendtures & & +6 & & $-G$ & & & & 0 \\
\hline Wages & $+W_{0}$ & $-W_{b}$ & & & & & & 0 \\
\hline $\operatorname{Tax}$ & $-T_{w}$ & $-T_{f}$ & & $+T$ & & $-T_{b}$ & $-T$ & 0 \\
\hline Retaind Profts (Frms) & & $-f_{u}$ & $+F u$ & & & & & 0 \\
\hline Utratains Profis (Frms) & & $-F d$ & & & & & $+F d$ & 0 \\
\hline CB and Bunk Profiss & & & & $+F_{c b}$ & $-F_{\phi}$ & $-F b$ & $+F b$ & 0 \\
\hline Interest in Bends & & & & $-i b_{-1} \cdot B_{-1}$ & & & $+i b_{-1}=B_{-1}$ & 0 \\
\hline Interest in Advanoes & & & & & $+i a_{-1}-A_{-1}$ & $-i Q_{-1} \cdot A_{-1}$ & & 0 \\
\hline Intersts in Loans & & $-I_{-1-1} L_{-1}$ & & & & $+i l_{-1} L_{-1}$ & & 0 \\
\hline$\Sigma$ & 0 & 0 & $+F u=I$ & $+\mathrm{Sav}_{\mathrm{g}}$ & 0 & 0 & $+\mathrm{Sav}_{f}$ & 0 \\
\hline$\Delta$ Deposts & & & & & & $+\Delta D$ & $-\Delta D$ & 0 \\
\hline$\Delta$ Bosds & & & & $+\Delta B$ & & & $-\Delta B$ & 0 \\
\hline A Advases & & & & & $-\Delta A$ & $+\Delta, A$ & & 0 \\
\hline A Loses & & & $+\Delta l$. & & & $-\Delta L$ & & 0 \\
\hline$\Sigma$ & 0 & 0 & 0 & 0 & 0 & 0 & 0 & 0 \\
\hline
\end{tabular}

Note: Positive sign (+) preceding a variable represents a resource destination and negative sign (-) represents a source

\section{THE MODEL STRUCTURE AND BEHAVIOR EQUATIONS}

In this section we will present the structure and the behavior equations of the economy at hand. In order not to confuse the reader with the notation, all variables will be expressed in nominal instead of real values.

\subsection{Price, Inflation and Income Distribution}

Regarding the behavior equations of the model we will consider a closed economy where firms operate in a market structure characterized by monopolistic competition. In this setting prices are formed by means of a mark-up over unit labor costs as expressed in Equation (1). We are assuming that labor is the only variable input used in production and its productivity $\left({ }^{q}\right)$ is assumed constant over time $^{12}$; i.e. there is no technical progress. The mark-up rate $(m)$ is not constant; but changes due to changes in the interest rate in loans, $i_{l}$, and on the level of capacity utilization of production inherited from the previous period, $u_{-1}$, as we can see in equation (2). The dependence of the mark-up rate to the interest rate in loans is a simple way to formalize the idea that the economy at hand is financialized in the sense that price decision - and hence income distribution - are directly linked with

12 This choice for constant productivity allows us to assume for simplicity that the working class can have a target of wage share. In this case, specifically, the result is similar to target some level of real wage. In cases where productivity is not constant, it is necessary to verify who is appropriating productivity gains in the distributive conflict. This, in the end, will imply a divergence of results between the two different specifications. 
financial variables ${ }^{13}$. Regarding the negative influence of capacity utilization on the rate of mark-up, we are simply adopting the new Keynesian perspective about counter-cyclical mark-up.

The profit share in income, $h$, is determined in equation (3), being dependent on the rate of mark-up. On the other hand, wage share can be obtained through the residual form by the subtraction of profit in the income, as it appears in (4).

Equation (5) shows the target value for the wage share that is demanded by labor unions, which is based in Rowthorn (1977). This target has an autonomous component, $\omega_{0}$, plus a component that captures the influence of the level of activity - represented by the level of capacity utilization, $u$-over income claims by unions. Equation (6), in turn, presents the wage inflation dynamics. Unions demand nominal wage increases in order to compensate the erosion of real wages by the inflation occurred in the previous period plus a component that captures the distributive conflict, given by the difference between the desired wage share by labor unions and the actual share, $\alpha_{1} \cdot\left(\omega^{d}-\omega\right)$.

$p=[1+m(\cdot)] \cdot \frac{W_{b}}{q}$

$m=m_{0}+m_{1} \cdot i_{l_{-1}}-m_{2} \cdot u_{-1}$

$h=\frac{\Pi}{Y}=\frac{m(\cdot)}{1+m(\cdot)}=\frac{m_{0}+m_{1} \cdot i_{l_{-1}}-m_{2} \cdot u_{-1}}{1+m_{0}+m_{1} \cdot i_{l_{-1}}-m_{2} \cdot u_{-1}}$

$\omega=1-h(\cdot)=\frac{1}{1+m_{0}+m_{1} \cdot i_{l_{-1}}-m_{2} \cdot u_{-1}}$

$\omega^{d}=\omega_{1}+\omega_{2} \cdot u$

$\widehat{w}_{b}=\left(1-\alpha_{1}\right) \cdot \hat{p}_{-1}+\alpha_{1} \cdot\left(\omega^{d}-\omega\right)$

$\hat{p}=\frac{m_{1} \cdot \Delta i_{l_{-1}}-m_{2} \cdot \Delta u_{-1}}{1+m_{0}+m_{1} \cdot l_{l_{-1}}-m_{2} \cdot u_{-1}}+\left(1-\alpha_{1}\right) \cdot \hat{p}_{-1}+\alpha_{1} \cdot\left(\omega_{1}+\omega_{2} \cdot u-\omega\right)$

$r_{k}=\frac{\Pi}{p \cdot K_{-1}}=h(\cdot) \cdot u(\cdot)$

Equation (7) summarizes the dynamics of inflation in the economy at hand. It is given by three parts. The first one is related to the mark-up dynamics, given by

\footnotetext{
13 A similar approach is adopted by Hein (2012, chapter 3$)$, where the mark-up rate depends on renti-
} ers' return on equity and bonds, instead of the interest rate on loans. 
$\left(m_{1} \cdot \Delta i_{l_{-1}}-m_{2} \cdot \Delta u_{-1}\right) /\left(1+m_{0}+m_{1} \cdot i_{l_{-1}}-m_{2} \cdot u_{-1}\right)$. The second part is the inertial component resulting from the backward looking of the unions regarding inflation expectations and the third part captures the distributive conflict.

Equation (8) shows the rate of return over productive capital in this economy. It is obtained by dividing total profits by the capital stock inherited from the previous period. Another way to calculate is by multiplying $h(\cdot) \cdot u(\cdot) \cdot{ }^{14}$

\subsection{Households}

\subsubsection{Consumption and Households Saving}

As previously shown, households are composed by workers and rentiers. Workers consume all their disposable income and consequently do not save or accumulate wealth. Thus, equation (9) shows that worker's consumption is the residue of wages, $W_{b}$, after the incidence of income tax, $\theta$.

Rentiers, in turn, will save all their available disposable income and will only consume a portion of the wealth inherited from the previous period. This is explicit in equation (10), considering that the propensity to spend of the inherited wealth is given by the interval $0<a \ll 1$.

By aggregating the consumption of the two classes, we have the aggregate consumption function that is presented in equation (11). This means that consumption is explained by the current level of disposable income and the inherited wealth of the previous period.

$C_{w}=(1-\theta) \cdot W_{b}$

$C_{r}=a \cdot V_{r_{-1}}$

$C=C_{w}+C_{r}=(1-\theta) \cdot W_{b}+a \cdot V_{r_{-1}}$

Where $C_{w}$ is the workers consumption, $C_{r}$ is the rentiers consumption, $\theta$ is a tax rate of income, ${ }^{a}$ is the wealth propensity for consumption, $C$ is the aggregate consumption, $V h_{-1}$ is an inherited rentiers wealth.

Nevertheless, we can use (11) in order to normalize consumption by the capital stock. Defining $\omega=W_{b} / Y$ and $u=Y / K_{-1}$, we get:

$14 \quad$ Assuming for simplicity and without loss of generality that capital-output ratio is equal to one. 
$c=(1-\theta) \cdot \omega \cdot u+a \cdot v_{r_{-1}}$

Where $\mathrm{c}$ is the normalized consumption by the stock of inherited capital, $C / K_{-1} ; \omega$ is the share of wages in income and $v r_{-1}$ is the inherited rentier's wealth divided by the stock of inherited capital.

\subsubsection{The Dynamics of Households Wealth}

The wealth of households is the sum of the wealth of the rentiers and the wealth of the workers. Since workers do not have wealth, then we have that $V_{h}=V_{r}$ , that is, the wealth of households is the wealth of the rentiers. Thenthe dynamics of wealth is given by:

$V_{r}=V_{r_{-1}}+S_{r}$

However, as part of the inherited wealth is consumed and all the current income of the rentiers after taxation is saved, we get:

$V_{r}=(1-a) \cdot V_{r_{-1}}+(1-\theta) \cdot\left(i_{b_{-1}} \cdot B_{-1}+F_{b}+F_{d}\right)$

Where $V_{r}$ is the wealth of the rentiers, $i_{b}$ is the interest rate of the public bonds, $F_{b}$ are the dividends received from the banks, $F_{d}$ are the dividends received from the firms.

\subsubsection{Portfolio of Rentiers ${ }^{15}$}

The rentiers allocate their wealth between only two financial assets: Deposits and Government Bonds. Rentiers endogenously modify their portfolio allocation according to changes in the spread between bond (long-term) interest and the advances (short-term) interest rate; and also due to changes in the level of economic activity, represented by disposable income. This is displayed in equations (13) and (14) below:

$$
\begin{aligned}
& B^{d}=\left[\lambda_{0}+\lambda_{1} \cdot\left(i_{b}-i_{a}\right)\right] \cdot V_{r_{-1}}-\lambda_{2} \cdot(1-\theta) \cdot Y \\
& D^{d}=\left[\left(1-\lambda_{0}\right)-\lambda_{1} \cdot\left(i_{b}-i_{a}\right)\right] \cdot V_{r_{-1}}+\lambda_{2} \cdot(1-\theta) \cdot Y \\
& V_{r} \equiv D^{d}+B^{d}
\end{aligned}
$$

$15 \quad$ This approach is Based on Tobin $(1980,1982)$. 
$B^{s}=B^{d}$

$D^{s}=D^{d}$

Where $B^{d}$ is the demand for bonds in current period, $\lambda_{0}$ is the autonomous component of the portfolio to allocate in bonds, $\lambda_{1}$ is the sensitivity parameter of the bonds demand to the spread between long term and short term interest rates, $i_{b}$ is the bond interest rate, $i_{a}$ is the advances interest rate, $D^{d}$ is the bank deposits demanded by rentiers.

Following Tobin's logic for portfolio construction ${ }^{16}$, we have some restrictions on parameter values. The first is that all wealth must be allocated between bank deposits and bonds, as stated by Red 1. The second constrain is that if there is a percentage increase in one asset, the other must be decreased by the same percentage. Other two redundant equations are given by Red2 and Red3, where all deposits (or bonds) supply must be equal to all demand.

\subsection{Government and Central Bank}

The Government is presented by equations (15) to (21). Equation (15) shows the government's tax revenue, which is obtained endogenously as a rate, $\theta$, over the level of economic activity. Note that this focuses on wages, profits in its broad conception that encompasses the real activity and financial activity of that economy. In order for there to be no double taxation, we define that dividend taxation occurs in the payment of the households.

Equation (16) shows that fiscal policy is designed for the government consumption to grow at the same rate of capital stock. Equation (17) shows the public sector borrowing requirement before the payment of interest on the debt ${ }^{17}$. Equation (18) shows the dynamics of public debt. The stock of bonds in the current period is given by the inherited bonds from previous period plus the payment of interest of inherited bonds plus the public sector borrowing requirement (PBR). Finally, in equation (19), we have that the profit of the Central Bank is given by the receipt of interest on the rediscount operations used by Commercial Banks.

$T=\theta \cdot d \cdot \Pi+\theta \cdot(1-d) \cdot \Pi+\theta \cdot W_{b}=\theta \cdot Y$

16 It is usual in the SFC literature to make use of the portfolio decision equations in the same way as did by James Tobin. Further details can be found in Chapter 3 of Godley, W. and Lavoie, M. (2007b).

17 Actually it is the primary deficit of public sector. 
$G=g_{0} \cdot K_{-1}$

$P B R=G-\left(T+F_{c b}\right)$

$B^{s}=\left(1+i_{b_{-1}}\right) B_{-1}^{s}+P B R$

$F_{c b}=i_{a_{-1}} \cdot A_{-1}$

Where $G$ is public expenditure, $g_{0}$ is desired ratio between government consumption expenditures and capital stock $P B R$ is the public sector borrowing requirement before interest payments over public debt, $B^{s}$ is the stock of government bonds issued and $F_{c b}$ is the profit of the central bank.

\subsection{The Term Structure of the Interest Rate}

The developed model makes use of two distinct interest rates. The first is equivalent to a short-term rate. It is used by the Central Bank as the one that pays the advance loans. It is settled by the means of a Taylor rule ${ }^{18}$ with the aim of being an instrument for the achievement of some numerical target for the inflation rate ( $\hat{p}^{T}$ ) in the long term. This means that monetary policy in the economy at hand is conducted under the Institutional Arrangement of the Inflation Targeting Regime ${ }^{19}$. This rule is presented in equation (20) and its behavior is explained by an inertial component (due to the so-called interest rate smoothing) and a component that captures the deviations of inflation from the target inflation.

The second, presented in equation (21), is the long-term interest rate ${ }^{20}$, that is, the interest rate on public debt securities, which is determined by the interaction between the supply of government securities, determined by the composition of financial wealth and public sector borrowing requirement, and the demand for then, given by the portfolio behavior of rentiers.

$i_{a}=i_{a-1}+\phi_{2} \cdot\left(\hat{p}_{-1}-\hat{p}^{T}\right)$

\footnotetext{
$18 \quad$ See Taylor (1993).

19 For a discussion about the different types of Institutional Arrangements of Inflation Targeting Regime see Oreiro and Rocha (2011).

20 Details on the derivation of the equation that determines the interest rate of government securities are presented in the appendix.
} 
$i_{b}=-\frac{\lambda_{0}}{\lambda_{1}}+i_{a}+\frac{(1-\tau)}{\lambda_{1}} \cdot i_{a_{-1}}+\frac{\left(1+i_{b-1}\right) B_{-1}^{s}+g_{0} \cdot K_{-1}-i_{a_{-1}} \cdot\left(L_{-1}+(1-\tau) \cdot B_{-1}\right)+\left[\lambda_{2} \cdot(1-\theta)-\theta\right] \cdot Y}{\lambda_{1} \cdot V_{r-1}}$

Where $\phi_{2}$ is the component that captures ${ }_{\hat{p}^{T}}^{\text {th }}$ current interest rate response to the deviation of past inflation from the target, .

\subsection{Comercial Banks}

The activity of the banking sector is described through equations (22) to (26). We suppose that interest rate on the bank loans is determined by applying a markup on the advances rate, according to equation (22).

Equation (23) indicates that a share of the bank deposits is maintained in the form of bank reserves in the central bank. Equation (24), in turn, shows that bank profits are calculated as the difference between the income received from interest on loans and the interest paid on advances. Its taxation occurs in the payment to the shareholders, since all banking profits are distributed to the households.

Equation (25) shows that loans in the current period are given by the sum of the loans inherited from previous period plus the difference between the desired investment by firms and the profits retained to finance it.

Equation (26) presents central bank loans to commercial banks. The loans demanded by the firms are fully supplied by the banks, so credit supply is fully endogenous. The liquidity for banks is provided by the rediscount operations conducted by central bank. In this way, we have the guarantee that there is unrestricted credit in the system.

$$
\begin{aligned}
& i_{l}=\left(1+\phi_{1}\right) \cdot i_{a} \\
& R \equiv \tau \cdot D \\
& F b=i_{l_{-1}} \cdot L_{-1}-i_{a_{-1}} \cdot A_{-1} \\
& L=L_{-1}+I-F u \\
& A \equiv L-(1-\tau) \cdot D
\end{aligned}
$$

Where $i_{l}$ is the interest rate of loans, $\phi_{1}$ is the mark-up of bank loans, $\tau$ is the share of deposits held as reserve within central bank, $R$ are the reserves, $D$ 
deposits, $F_{b}$ is the profit from banking activity, $L$ are the loans.

\subsection{Firms}

The equations that define the behavior of firms are given by (27) to (32). Equation (27), in turn, presents the investment rate. It is given by an autonomous component, $\gamma_{0}$ and a component, $\gamma_{1}$, which captures the difference between the return on economic activity and the interest rate on loans. This specification of the investment function is based on Robinson (1956).

Equation (28) presents the calculation of profit before taxes. In order to avoid double taxation, the model assumes that dividends are taxed only after they are distributed, that is, households are responsible for their payment and firms pay for the share that is retained. Profit is calculated directly through the profit share times the national income minus the interest payment over loans.

Equation (29) shows that dividends are a percentage share, $d$, of total profit after payment of interest on loans. The equation (30) complements the idea showing that the retained profits are equal to total profits times the retention coefficient (1-d) times one minus the tax rate. Finally, (31) and (32) reveals the dynamics of capital that is given by accumulated capital until previous period plus gross investment and the investment level is given by investment rate times the lagged capital stock. For simplicity, we consider that there is no depreciation of productive capital.

$$
\begin{aligned}
& \text { in }=\frac{\Delta K}{K_{-1}}=\gamma_{0}+\gamma_{1} \cdot\left(r_{k}-i_{l}\right) \\
& F=h \cdot Y-i_{l_{-1}} \cdot L_{-1} \\
& F d=d \cdot F, \quad 0<d<1 \\
& F u=(1-\theta) \cdot(1-d) \cdot F \\
& K=K_{-1}+I \\
& I=\text { in. } K_{-1}
\end{aligned}
$$




\section{REDUCED MODEL VERSION}

In this section we will present the reduced version of the model. Although it is not usual in the SFC literature to use this type of approach, we chose to simplify the model by replacing and manipulating algebraically until it was possible to take the complete system of 32 equations and transform it into one of only 9 difference equations.

To that end, the variables that grow at the level, such as $Y, C, I, B, V_{r}$, among others, were normalized by dividing by the stock of capital, which also grows in level. The advantage in doing this is that in the end we have a system that can converge to a steady state rather than just providing a balanced growth path.

In addition, we can through the reduced system, perform the calculation of the partial derivatives and infer the short-term links and whether these assume positive or negative values (when is possible to define without numerical calculus).

Thus, we present the first equation that represents inflation. It has three terms that need to be analyzed. The first one is called mark-up inflation, described by $\left(m_{1} \cdot\left(1+\phi_{1}\right) \cdot \Delta i_{a_{-1}}-m_{2} \cdot \Delta u_{-1}\right) /\left(1+m_{0}+m_{1} \cdot\left(1+\phi_{1}\right) \cdot i_{a_{-1}}-m_{2} \cdot u_{-1}\right)$ . This term represents the price mark-up change of firms over time and in the steady state it converges to zero. The second term is the inertial component of inflation, given by $\left(1-\alpha_{1}\right) \cdot \hat{p}_{-1}$ and the third captures the conflict claim, given by $\alpha_{1} \cdot\left[\omega_{1}+\omega_{2} \cdot u-(1-h)\right]$.

$\hat{p}=\frac{m_{1} \cdot\left(1+\phi_{1}\right) \cdot \Delta \cdot i_{a_{-1}}-m_{2} \cdot \Delta u_{-1}}{1+m_{0}+m_{1} \cdot\left(1+\phi_{1}\right) \cdot i_{a_{-1}}-m_{2} \cdot u_{-1}}+\left(1-\alpha_{1}\right) \cdot \hat{p}_{-1}+\alpha_{1} \cdot\left[\omega_{1}+\omega_{2} \cdot u-(1-h)\right]$

Next, we have the $u$ curve (or IS curve) of the economy created in equation (34). In it we have the term which is the well-known Keynesian multiplier, given by $1 /\left(\theta+\gamma_{2}+a_{3} \cdot h\right)$, where $a_{3}=\left[(1-\theta)-\gamma_{1}\right]$. As can be noted, the multiplier rises as wage share increases (and profit-share decreases). The autonomous components in period $t$ are $A_{1}+a \cdot v_{r_{-1}}$, where $A_{1}=\gamma_{0}+g_{0}$. As the curve also shows, the higher the interest rate, the lower will be the level of capacity utilization.

$u=\frac{1}{\theta+\gamma_{2}+a_{3} \cdot h}\left(A_{1}+a \cdot v_{r_{-1}}-\gamma_{1} \cdot z_{1} \cdot i_{a}\right)$

Equations (35) and (36) have been presented previously. The first is the equation that provides the Taylor rule that defines the dynamics of the short-term interest rate while the second defines the interest rate of the public bonds necessary to clear capital markets. 


$$
\begin{aligned}
& i_{a}=i_{a_{-1}}+\phi_{2} \cdot\left(\hat{p}_{-1}-\hat{p}^{T}\right) \\
& i_{b}=-\frac{\lambda_{0}}{\lambda_{1}}+i_{a}+\frac{(1-\tau)}{\lambda_{1}} \cdot i_{a_{-1}}+\frac{g_{0}+\left[1+i_{b_{-1}}-(1-\tau) \cdot i_{a_{-1}}\right] \cdot b_{-1}-i_{a_{-1}} l_{-1}+\left[\lambda_{2} \cdot(1-\theta)-\theta\right] \cdot u}{\lambda_{1} \cdot v_{r_{-1}}}
\end{aligned}
$$

Equations (37) and (38) present the dynamics of profit-share and investment. The profit-share has already been exposed in the complete model, while the investment equation has been simplified here to make the transmission channels clear. It has an autonomous parameter representing the "animal spirits", a parameter of sensitivity to changes in capacity utilization and profit-share and another parameter of sensitivity to the interest rate.

$$
\begin{aligned}
& h=\frac{m_{0}+m_{1} \cdot\left(1+\phi_{1}\right) \cdot i_{a_{-1}}-m_{2} \cdot u_{-1}}{1+m_{0}+m_{1} \cdot z_{1} \cdot i_{a_{-1}}-m_{2} \cdot u_{-1}} \\
& \text { in }=\gamma_{0}+\gamma_{1} \cdot\left(h \cdot u-\left(1+\phi_{1}\right) \cdot i_{a}\right)
\end{aligned}
$$

Equations (39), (40) and (41) present the dynamics of the public debt normalized by the stock of capital, loans normalized by the stock of capital, and the wealth of rentiers normalized by the stock of capital.

$$
\begin{aligned}
& b=\frac{\left[1+i_{b_{-1}}-(1-\tau) \cdot i_{a_{-1}}\right] \cdot b_{-1}+\gamma_{0}-\theta \cdot u-i_{a_{-1}} \cdot\left[l_{-1}-(1-\tau)\right]}{1+i n} \\
& l=\frac{\left[1+\left(1+\phi_{1}\right) \cdot i_{a_{-1}}\right] \cdot l_{-1}+i n-(1-\theta) \cdot(1-d) \cdot h \cdot u}{1+i n} \\
& v_{r}=\frac{\left[1-a+(1-\tau) \cdot i_{a_{-1}}\right] \cdot v_{r_{-1}}+(1-\theta)\left\{\left[i_{b_{-1}}-(1-\tau) \cdot i_{a_{-1}}\right] \cdot b_{-1}+\left[(1-d)\left(1+\phi_{1}\right)-1\right] \cdot i_{a_{-1}} l_{-1}+d \cdot h \cdot u\right]}{1+i n}
\end{aligned}
$$

\subsection{Short-run link among the variables}

As mentioned earlier, from the reduced system, we have an easier work to establish the short-term connections between the current and lagged variables of the system. We have 55 partial derivatives of 116 possible combinations between variables. We will comment on some of them in the sequence and these are presented in table 3 below.

First, let's talk about inflation. This variable increases with the increase in rate of capacity utilization, falls with the increase of the short-term interest rate, rises with the increase of inertial inflation (lagged) and may have a positive or neg- 
ative relation with the inherited capacity utilization and the rate of lagged short-term interest, depending on the values of the parameters used.

Table 3 - Short-run link among the variables of SFC Model

\begin{tabular}{|c|c|c|c|c|c|c|c|c|c|c|c|c|c|c|c|c|}
\hline & \multicolumn{16}{|c|}{ Short-ren time anvong sariables } \\
\hline & \multicolumn{9}{|c|}{ Actral Variables } & \multicolumn{7}{|c|}{ Lagged Variables } \\
\hline & $\cdots$ & $\cdots$ & 4. & $\because$. & $\cdots$ & $\cdots$ & $\cdots$ & 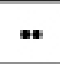 & $\because$ & $\bullet$. & $\because$. & $\because$. & $\because$, & $\because \ldots$ & "... & $\therefore$. \\
\hline$\cdots$ & - & $>0$ & $<0$ & - & $>0$ & - & - & - & - & $>0$ & $?$ & $?$ & - & - & - & - \\
\hline$\cdots$ & - & - & $<0$ & - & $<0$ & - & - & - & - & $<0$ & - & $<0$ & - & - & - & $>0$ \\
\hline$\because$. & - & - & - & - & - & - & - & - & - & $>0$ & - & $>0$ & - & - & - & - \\
\hline$\because$. & - & $>0$ & $>0$ & - & - & - & - & - & - & $>0$ & - & $>0$ & $>0$ & $>0$ & $<0$ & $<0$ \\
\hline$\cdots$ & - & - & - & - & - & - & - & - & - & - & $<0$ & $>0$ & - & - & - & - \\
\hline$\cdots$ & - & $>0$ & $<0$ & - & $>0$ & - & - & - & - & $<0$ & $?$ & $?$ & - & - & - & $>0$ \\
\hline$\cdots$ & - & $?$ & $?$ & - & - & $<0$ & - & $<0$ & - & - & - & $?$ & $>0$ & $>0$ & $<0$ & - \\
\hline$*$ & - & $?$ & - & - & $?$ & $?$ & - & - & - & $?$ & - & ? & - & - & $>0$ & - \\
\hline$\because$ & - & $?$ & $?$ & - & $?$ & $<0$ & - & - & - & $?$ & $?$ & $?$ & $>0$ & $?$ & $>0$ & $>0$ \\
\hline
\end{tabular}

Following, we have the $u$ curve that undergoes negative variations when: the short-term interest rate rises, the profit-share rises, the inflationary inertia rises and the inherited interest rate rises. It undergoes positive variations when the normalized inherited wealth rises.

With respect to the short-term interest rate, this rises when inertial inflation increases or when the lagged short-term interest rate increases. The interest rate on government bonds rises when capacity utilization increases, short-term interest rate increases, inertial inflation increases, lagged short-term interest rate increases, interest rate of inherited bonds increases, and inherited stock of bonds normalized by the capital stock increases. The rate undergoes negative variations when there are increases in the stock of inherited loans normalized by the stock of capital and when inherited wealth normalized by the stock of capital also increases.

We can also show that profit share increases with positive changes in the lagged interest rate on loans and falls with the increase in the lagged capacity utilization. The investment rate increases due to increased capacity utilization, increased profit share and increased inherited wealth. It is negatively related to the interest rate and to inflationary inertia.

The last three variables are the normalized stocks of bonds, loans, and rentier wealth. The first one has positive variations when there is an increase of the interest rate of inherited bonds and an increase of the stock of normalized bonds inherited. There are negative variations when there is an increase in the invest- 
ment rate or there is an increase in the normalized stock of current and lagged loans. The relationship can be positive or negative depending on the parameters for the following variables: capacity utilization, current and inherited short-term interest rates.

The second stock, the normalized loans, shows increases when we have an increase in lagged normalized loans. The partial derivative signs can be positive or negative for: capacity utilization, profit-share, investment rate, inherited inflation, and inherited interest rate.

Finally, the third stock, presented in (41) by the equation that gives the normalized wealth dynamics of the rentiers, indicates the following relations: positive increases when the interest rate increases inherited from government bills, bank loans and rentier wealth both lagged.

\subsection{Long-run stability and growth regimes}

\subsubsection{The Steady State}

In this section we will define the fixed points that must be found in the steady state of the model. It will not be possible to isolate the variables only in function of the parameters. However, even if this is not possible, it is important to separate the points to investigate possible indeterminations or overdeterminations of the system. Thus, we have the following steady state values:

Inflation:

As the monetary authority will raise short term interest rate up to the level that is required for inflation does not deviate from the target ${ }^{21}$, in the steady state we will have:

$$
\hat{p}^{*}=p^{T}
$$

Capacity Utilization:

Since capacity utilization is the adjustment variable of distributive conflict, in the steady state that level had to be compatible with the value that can bring inflation to the target. Therefore, we have from (33) that:

$$
u^{*}=\frac{1}{\omega_{2}}\left(\hat{p}^{T}+\omega^{*}-\omega_{1}\right)
$$

$\overline{21} \quad$ This condition will be fulfilled if $\phi_{2}>1$ 
Interest Rate on Advances:

As equation (33) determines the level of $u^{*}$, the equation (34) allows us to determine the level of the short-term interest rate in the steady state. In this way, we have:

$i_{a}^{*}=\frac{1}{A_{2}} \cdot\left[\left(A_{1}+a \cdot v_{r}^{*}\right)-\frac{1}{\psi_{1} \cdot \omega_{2}} \cdot\left(\hat{p}^{T}+\omega^{*}-\omega_{1}\right)\right]$

Where $A_{1}=\gamma_{0}+g_{0} ; \quad \psi_{1}=1 /\left\{1-(1-\theta)+\gamma_{2}+\left[(1-\theta)-\gamma_{1}\right] . h^{*}\right\} ;$ $A_{2}=\gamma_{1} \cdot z_{1}$.

Interest Rate on Government Bonds:

Using the same previous criteria, from equation (36), we have the following equation (45). As can be noted, the interest rate value depends on the parameter values to be positive and higher than the short-term interest rate. For this reason, during our simulations, we need to restrict the parameter values so that the model result makes economic sense.

$i_{b}^{*}=-\frac{\lambda_{0} \cdot v_{r}^{*}}{\lambda_{1} \cdot v_{r}^{*}-b^{*}}+\frac{\left[\lambda_{1}+(1-\tau)\right] \cdot i_{a}^{*} \cdot v_{r}^{*}}{\lambda_{1} \cdot v_{r}^{*}-b^{*}}+\frac{b^{*}+g_{0}-i_{a}^{*} \cdot\left[l^{*}+(1-\tau) \cdot b^{*}\right]+\left[\lambda_{2} \cdot(1-\theta)-\theta\right] \cdot u^{*}}{\lambda_{1} \cdot v_{r}^{*}-b^{*}}$

Profit-share:

Regarding the profit-share, the direct result of the steady state is expressed by the following equation (46). The result dispenses other comments. Mathematically it is clear that we must have $m_{0}+m_{1} \cdot z_{1} \cdot i_{a}^{*}>m_{2} \cdot u^{*}$ in order for the model to have economic sense.

$$
h^{*}=\frac{m_{0}+m_{1} \cdot z_{1} \cdot i_{a}^{*}-m_{2} \cdot u^{*}}{1+m_{0}+m_{1} \cdot z_{1} \cdot i_{a}^{*}-m_{2} \cdot u^{*}}
$$

Investment Rate:

Again, regarding the investment rate, the direct result of the steady state is:

$$
i n^{*}=\gamma_{0}+\gamma_{1} \cdot h \cdot u^{*}-\gamma_{1} \cdot z_{1} \cdot i_{a}^{*}
$$

Bonds-Capital Ratio:

The level of indebtedness in the steady state depends positively on the autonomous expenditure of the economic activity and negatively on the profit received 
by the CB. For the value to be positive, we must have $\gamma_{0}>\theta \cdot u^{*}+i_{a}^{*} \cdot\left(l^{*}-v_{r}^{*}\right)$ and $i n^{*}>\left(i_{b}^{*}+i_{a}^{*}\right) /\left(1-i_{a}^{*}\right)$.

$$
\begin{aligned}
& b^{*}=\frac{\gamma_{0}-\theta \cdot u^{*}-i_{a}^{*} \cdot\left(l^{*}-v_{r}^{*}\right)}{\left(1-i_{a}^{*}\right) \cdot i n^{*}-i_{b}^{*}-i_{a}^{*}} \\
& l^{*}=\frac{\gamma_{0}-\gamma_{1} \cdot z_{1} \cdot i_{a}^{*}+\left[\gamma_{1}-(1-\theta) \cdot(1-d)\right] \cdot h^{*} \cdot u^{*}}{\gamma_{0}+\gamma_{1} \cdot h^{*} \cdot u^{*}-\left(1+\phi_{1}+\gamma_{1} \cdot z_{1}\right) \cdot i_{a}^{*}}
\end{aligned}
$$

Rentier's Wealth-Capital Ratio.

$$
v_{r}^{*}=\frac{(1-\theta)\left\{\left[i_{b}^{*}-(1-\tau) \cdot i_{a}^{*}\right] \cdot b^{*}-\left[1-(1-d)\left(1+\phi_{1}\right)\right] \cdot i_{a}^{*} \cdot l^{*}+d \cdot h^{*} \cdot u^{*}\right\}}{\gamma_{0}+a+\gamma_{1} \cdot h \cdot u^{*}-\left(1-\tau+\gamma_{1} \cdot z_{1}\right) \cdot i_{a}^{*}}
$$

\subsubsection{Growth Regimes (Wage or Profit Led?) ${ }^{22}$}

In this work we used an algorithm developed by Costa Santos (2017) to find the parameters for the model that generate steady state. Briefly, the algorithm is developed in the following steps:

Generation of random parameters through a plausible economic interval.

Model resolution via Gauss-Seidel using these random parameters as input. Storage of reduced model variables when $t=1000$.

Separate $\Delta \hat{p}, \Delta u, \Delta h, \Delta i n, \Delta i_{a}, \Delta i_{b}, \Delta b, \Delta l, \Delta v_{r}<10^{-6}$ (tolerance).

From the filtered data, it is calculated for $t=1000$ the values of $\Delta u / \Delta h$ and $\Delta i n / \Delta h$.

If $\Delta u / \Delta h>0$ and $\Delta i n / \Delta h>0$, Profit-led demand and accumulation regimes. Wage-led, otherwise.

Having explained the steps of the above algorithm, we present figure 1, in the sequence, with the results obtained for $10^{9}$ simulations, which finally could be separated the wage led and profit led regimes and estimated in a non-parametric way the density probability via Kernel.

The use of this type of methodology allows us to separate parameters to later carry out simulations with this calibration and to investigate the general properties of the model for each of the two possibilities of growth regime.

22 Regarding different demand and accumulation regimes see Rowthorn (1981) and Marglin and Bhaduri (1990). 

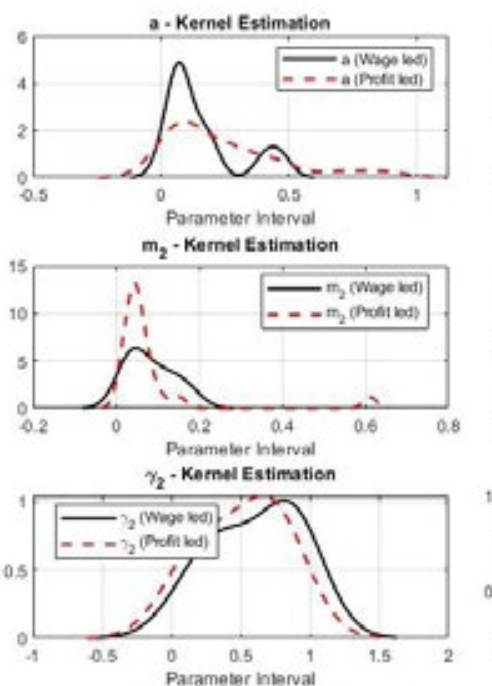

$\phi,-$ Kermet Estimation

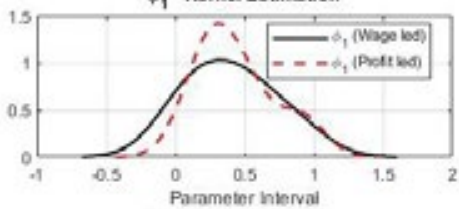

Parameter hiverval
$\lambda_{1}$ - Kernel Estimation

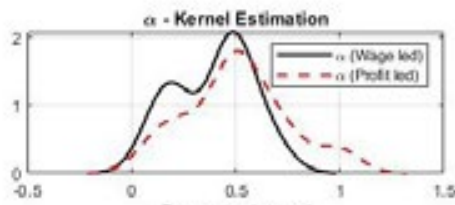

Parameter hnenval

6. Kernel Estimation

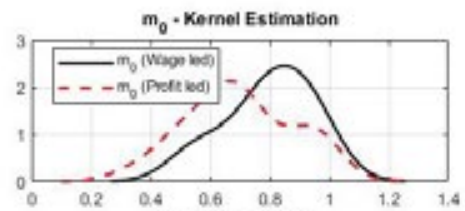

Paramenter interval

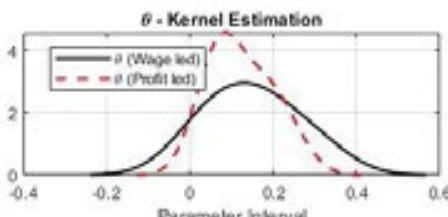

Parameler hinterval
go - Kornel Estimation

-

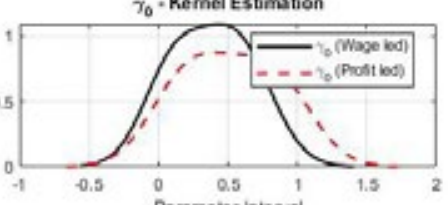

Parameser interval
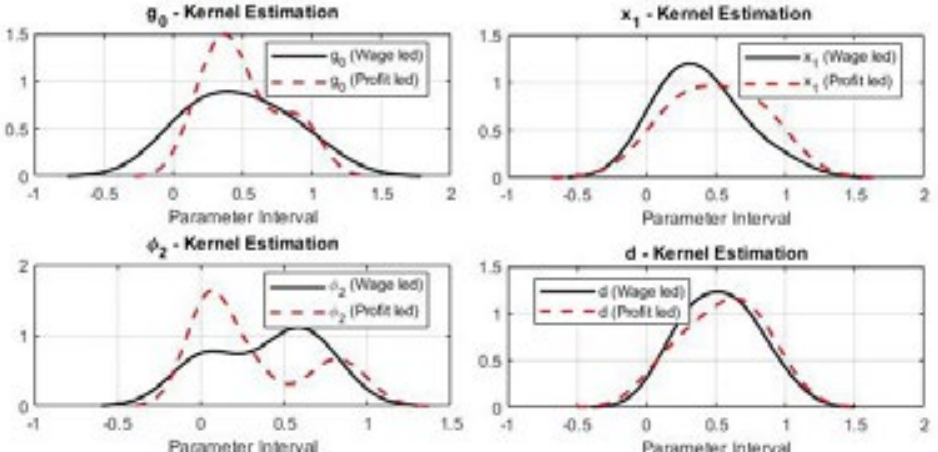

$\lambda_{2}$ - Kernet Estimation

Parameser Interval
$\omega_{1} \cdot$ Kemel Estimation

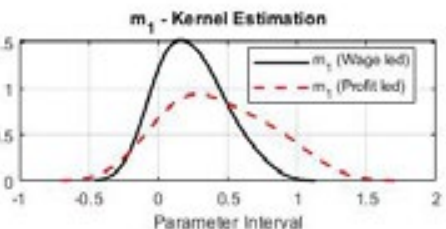

Parameser Interval
$\gamma_{1} \cdot$ Kernel Estimation

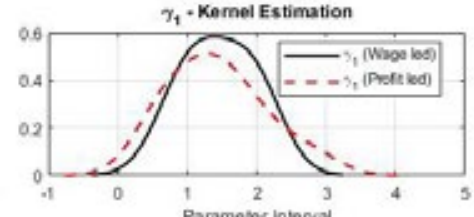

12

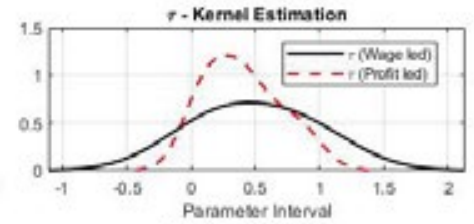

0.5
Parameser interval
$\lambda_{0}-$ Kenmel Eatimation

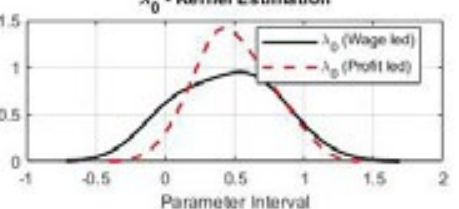

Parameser Inleval
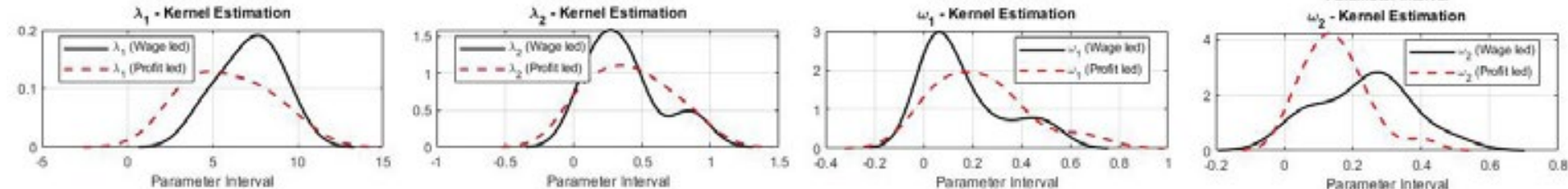

Figure 1 - Kernel Density for Parameters and Growth Regimes

29

REVISTA PRÁTICAS DE ADMINISTRAÇÃO PÚBLICA

$$
\begin{gathered}
\text { VOL. } 4 \text {, № 3. SET./DEZ. } 2020 \\
03-42
\end{gathered}
$$




\section{CALIBRATION, SIMULATION AND RESULT23}

\subsection{Baseline Scenario and Steady State}

The complete model was simulated based on the parameters and exogenous variables described in table 4 below. The first result to be reported is the baseline scenario which describes the convergence of the model to steady state.

Table 4 - Parameters Used in Baseline Simulation

\begin{tabular}{|c|c|c|c|}
\hline Parameter & Value & Parameter & Value \\
\hline $\boldsymbol{a}$ & 0.04 & $m_{1}$ & 0.20 \\
\hline $\boldsymbol{\alpha}_{1}$ & 0.15 & $m_{2}$ & 0.20 \\
\hline $\boldsymbol{d}$ & 0.25 & $\omega_{1}$ & 0.40 \\
\hline $\boldsymbol{g}_{0}$ & 0.05 & $\omega_{2}$ & 1.00 \\
\hline $\boldsymbol{\gamma}_{0}$ & 0.04 & $\phi_{1}$ & 0.50 \\
\hline$\lambda_{0}$ & 0.30 & $\phi_{2}$ & 0.25 \\
\hline$\lambda_{1}$ & 100 & $\tau$ & 0.10 \\
\hline$\lambda_{2}$ & 0.50 & $\theta$ & 0.20 \\
\hline $\boldsymbol{m}_{0}$ & 0.50 & $\hat{p}^{T}$ & 0.04 \\
\hline
\end{tabular}

Figure 2 below shows in the first quadrant to the left the paths of the components shares of GDP from the demand approach. As it is a closed economy, we have $C / Y+G / Y+I / Y=1$. In this way, we have that $C / Y$ converges to values close to $60 \%$ while the other variables converge to $20 \%$ each.

In the second upper quadrant to the right, we have the path of public and private debt in this economy, these both variables over the GDP. In the baseline scenario, we then have the convergence of public debt to values around $20 \%$ of GDP and private debt to approximately $40 \%$ of GDP.

In the third quadrant, which is in the second row of the first column, we have the profit share and the wage share of this economy converging to the steady state. The wage share converges to a value around $70 \%$ while the profit share to close to $30 \%$, obviously both having to add up to $100 \%$.

In the fourth quadrant, which is in the second row and second column of figure 2, we have the dynamics of inflation in this economy. We have that for the

\footnotetext{
23 Regarding calibration and simulation of SFC models see O'Shea and Kinsella (2016) and Kinsella
} and O'Shea (2017). 
values used in the simulation, the monetary policy is efficient in being able to take the path of the inflation towards the established goal. Thus, in the steady state, $\hat{p}=p^{T}$.

In the fifth quadrant of the same figure, third row and first column, we have the dynamics of short-term and long-term interest rates. In this baseline scenario we can see that the short is lower than the long, which at first can be affected depending on the shocks that reach that economy.

In the sixth quadrant, we have the portfolio behavior of the rentiers. There we find that in the steady state the wealth is shared between $20 \%$ in bonds and $80 \%$ in deposits. The last two quadrants present the dynamics of the investment rate, which converges to values between 6 and $8 \%$ and, in the sequence, we have the use of the productive capacity that converges to values between $70 \%$ and $80 \%$, so that the observed trajectories of this simulated economy are similar to the capitalist experience observed so far. 

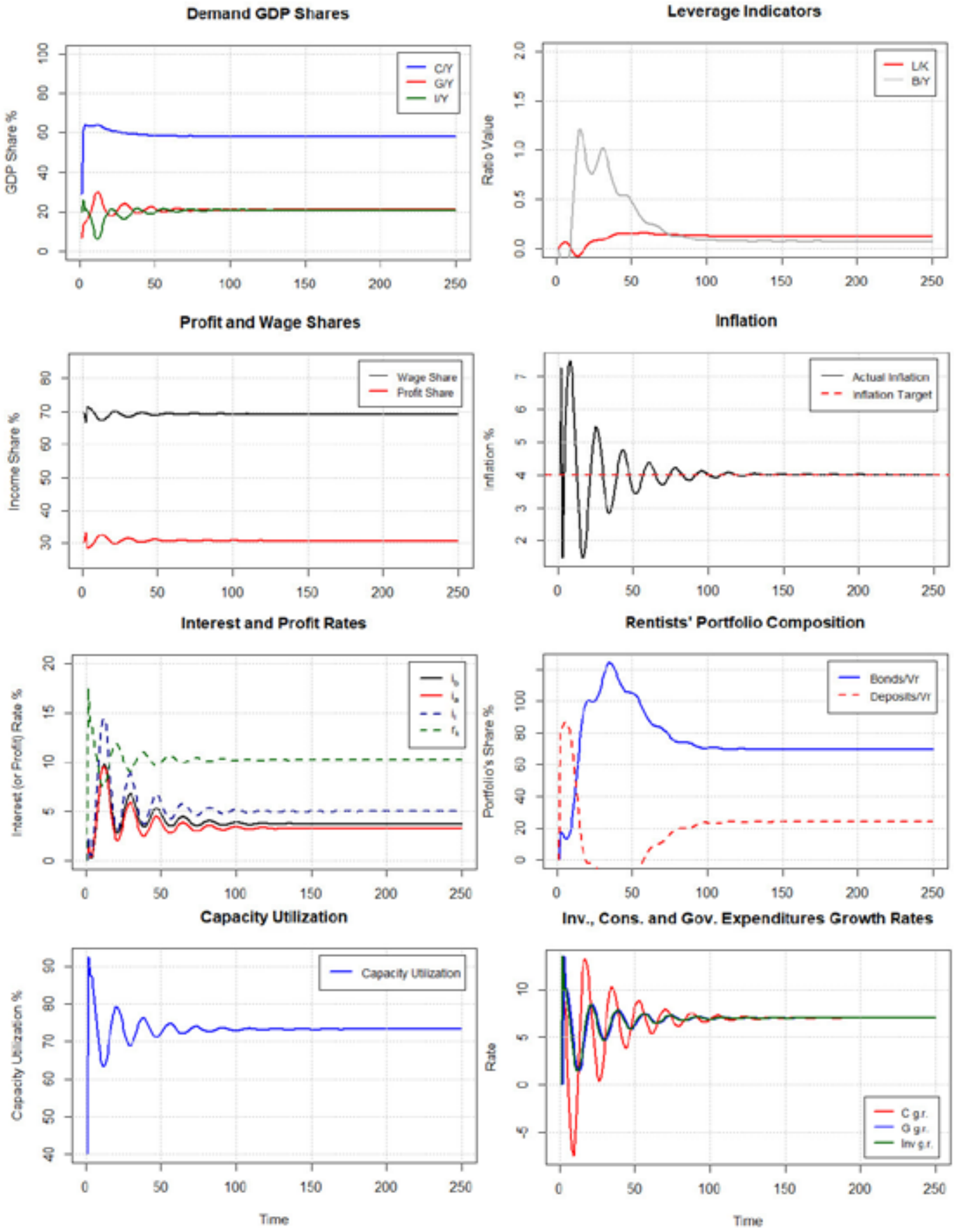

Figure 2 - Baseline Model Dynamics

Still on the model in base scenario, we present figure 2 that brings the results of the growth regime of the model. There are four quadrants with the following paths: Wage Share $\times$ Capacity Utilization; Wage Share $\times$ Investment Rate; Profit Share $\times$ Capacity Utilization; Profit Share $\times$ Investment Rate. The convergence 
to the steady state between the variables makes it clear that the growth regime is wage-led, since there is a positive relation between the investment rate and the capacity utilization with the wage share.
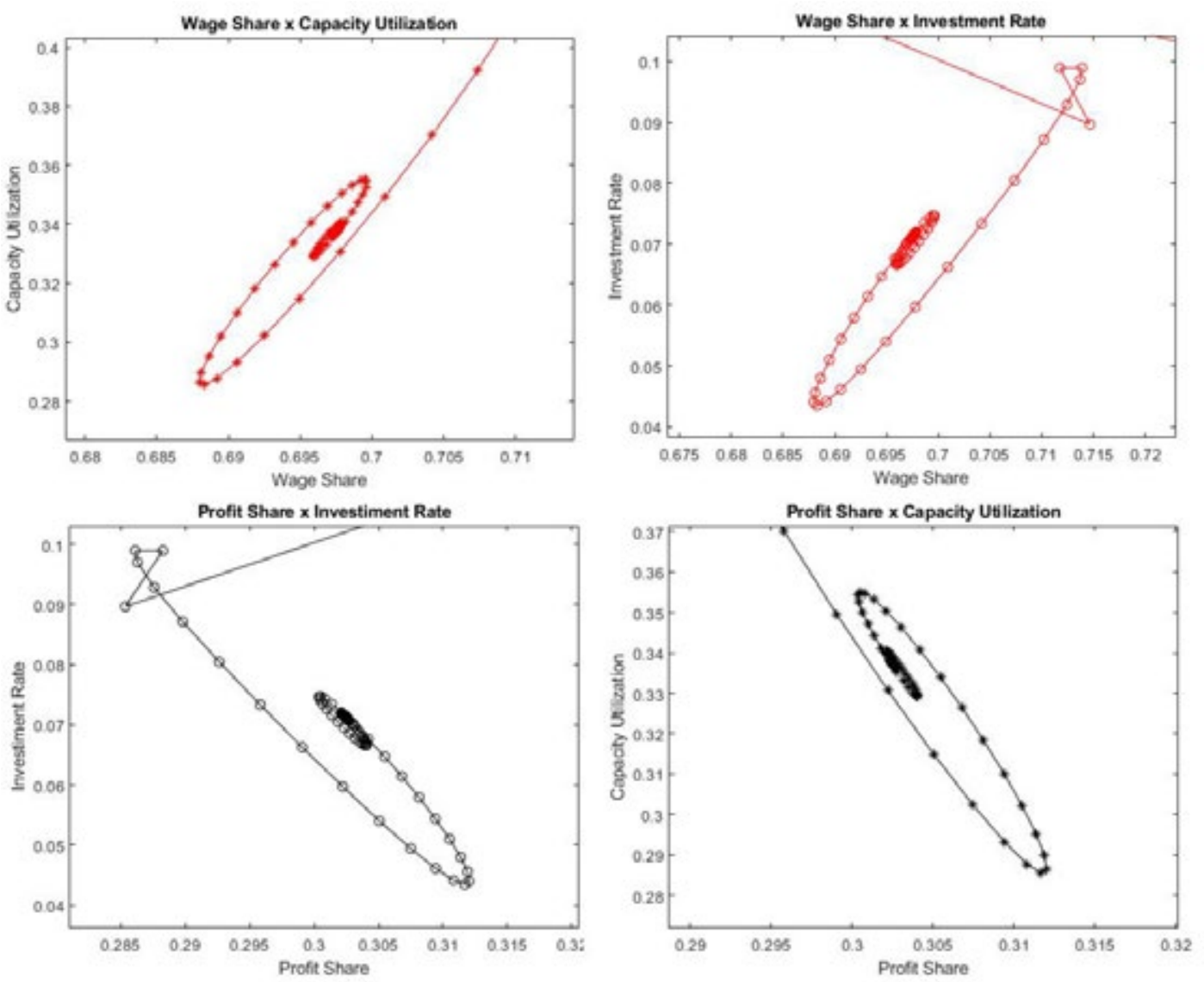

Figure 3 - Growth Regime in Baseline Simulation

\subsection{Shocks - Increase of Desired ratio of Government Consumption to Capital Stock}

After analyzing the time path of the model for the base scenario, we show the results after an exogenous shock was applied to a parameter of the model. More precisely, we applied a shock af $14 \%$ increase in the desired ratio of government consumption to capital stock, ${ }_{0}$, representing an increase in the level of government expenditure in a permanent way ${ }^{24}$.

The results of the shock are presented in figure 4 and 5 . In figure 4 , we have an important result of the model. The increase in the level of government expendi-

$24 \quad$ Unlike IRF in VARs (Econometric Approach) that give a one-time point shock and observe the trajectory of the endogenous variable, here the shock is a permanent change of the parameter value. 
tures produces a crowding-out effect over private investment, in a sense that the increase in the ratio of government consumption over GDP resulted in a one to one reduction in the ratio of investment to GDP. Since the ratio of investment to GDP is one of the main determinants of the growth rate of capital stock, then an increase in the level of government expenditures will produce a reduction of the pace of capital accumulation in the long term. We will explain the mechanism behind these effects in sequence and show it in figure 4.

The crowding-out mechanism of the model basically occurs through the following channels: by raising an exogenous component of demand; there will occur immediately an increase in the level of capacity utilization. This effect increases the level of conflict over income distribution since target wage share increases, which in turn accelerates inflation.

In the next turn, the monetary authority perceiving the deviation of inflation to the target; starts to raise the short-term interest rate to decrease aggregate demand and capacity utilization. In doing so, there will be an increase in the equilibrium level of short-term interest rate that will also raise the long-term interest rate and the cost of capital; having a negative impact over investment decisions.

At the same time, since public spending increases but investment decreases, the net effect on the level of activity is almost nil. This will produce an increase in the public borrowing requirement over GDP. As a result, we have an increase in longterm interest rate. A schematic summary of these channels is shown in Figure 4.

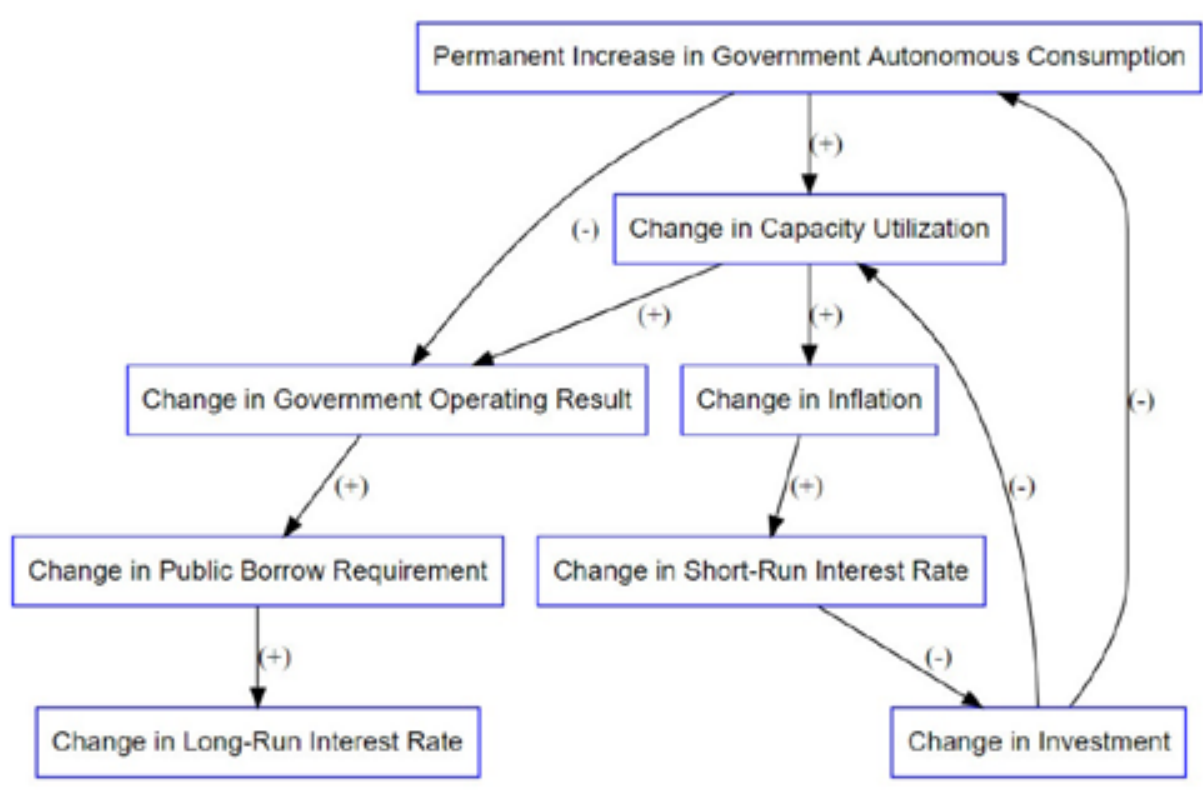

Figure 4: Model's Links Among Variables 
Although it is unusual crowding-out effects in both Post-Keynesian literature and in SFC approach, we can clearly explain the mechanism in the light of our model.

Through the results obtained in the simulations, the presence of the monetary policy driven by a Taylor rule plus an expansionary fiscal policy is responsible for the Crowding-out result. In addition, the crowding-out is the responsible to link the increase in the short interest rate to the increase in long one, since the effect on the level of activity is nil as mentioned before.

An important point that should also be highlighted regarding the dynamics of inflation in the model is that before defining the Taylor rule equation, we tested three different forms, which are:

$$
\begin{aligned}
& i_{a}=\left(1-\phi_{1}\right) \cdot i_{a_{-1}}+\phi_{1} \cdot \overline{i_{a}}+\phi_{2} \cdot\left(\hat{p}_{-1}-\hat{p}^{T}\right) \\
& i_{a}=\left(1-\phi_{1}\right) \cdot i_{a_{-1}}+\phi_{2} \cdot\left(\hat{p}_{-1}-\hat{p}^{T}\right) \\
& i_{a}=i_{a_{-1}}+\phi_{2} \cdot\left(\hat{p}_{-1}-\hat{p}^{T}\right)
\end{aligned}
$$

Where $\overline{i_{a}}$ is an exogenous interest rate determined by conventions or institutional arrangement. [As mentioned by Smithin (2006)].

The result of the first specification was: The increase in interest rate cannot bring the actual inflation to the target, since there are two aims (drive the interest rate to a conventional value in the long run and use it to mediate the distributive conflict and drive inflation towards the Central Bank target) and just a single instrument in controlling inflation.

The result of the second specification was that inflation converges to a value in the proximity of the inflation target. But there is no asymptotic convergence to the target.

The result of the third was: Asymptotic convergence of actual inflation to the established target. We believe that the reason for this result is that the other specifications violate the Tinbergen Economic Policy theorem (1956), in which there would be two aims (to keep inflation on target and to keep the product in the potential product) and a single instrument (the rate of short-term interest). This result also reinforces what was found by Godley and Lavoie (2007a), as well as Greenwood-Nimmo (2013) about the need for joint use of fiscal and monetary policy.

To summarize the idea, any increasing in public spending needs to be financed by an increase in taxation or issuance of new bonds, when money financing of government deficits is forbidden by law. As expected, the initial effect over 
capacity utilization of an increase in government expenditure is expansionary, according to the second quadrant of figure 5 .

Thus, as the expansionary fiscal policy causes inflation to deviate from the target ${ }^{25}$, monetary policy is triggered to raise the short-term interest rate, in order to reduce the level of activity and drive actual inflation to the inflation target. The result of initial shock unbalances the government's primary budget, according to quadrant 8 of Figure 5 . Throughout the transitional dynamics, the budget converges to approximately $-1 \%$ of deficit and to a stable debt-to-GDP ratio.

Regarding the effects of increasing government expenditures over income distribution, we can see that the effect on profit-share is initially to decrease and then to converge to a higher level. As the level of capacity utilization falls slightly, the net effect on the profit rate is almost neutral. The same cannot be said about the interest rate on loans. As the $\mathrm{CB}$ raises the interest rate to overthrow economic activity and reduce inflation to the target level, there will be an increase in the interest rate on loans and a net fall in the spread of profit rate over interest rate on loans, according to the sixth quadrant of figure 4 , which also contributes to the reduction of the pace of capital accumulation.

Finally, we also have a new set of values for the balanced growth path. As we can see easily in figure 5 , steady-state growth rates of investment, consumption and government expenditures are lower after the shock over fiscal policy.

$25 \quad$ The link between the expansionary fiscal policy and the increase in inflation occurs through a conflict claims. 
InV, Cons, and Gov. Expenditures Growth Rates
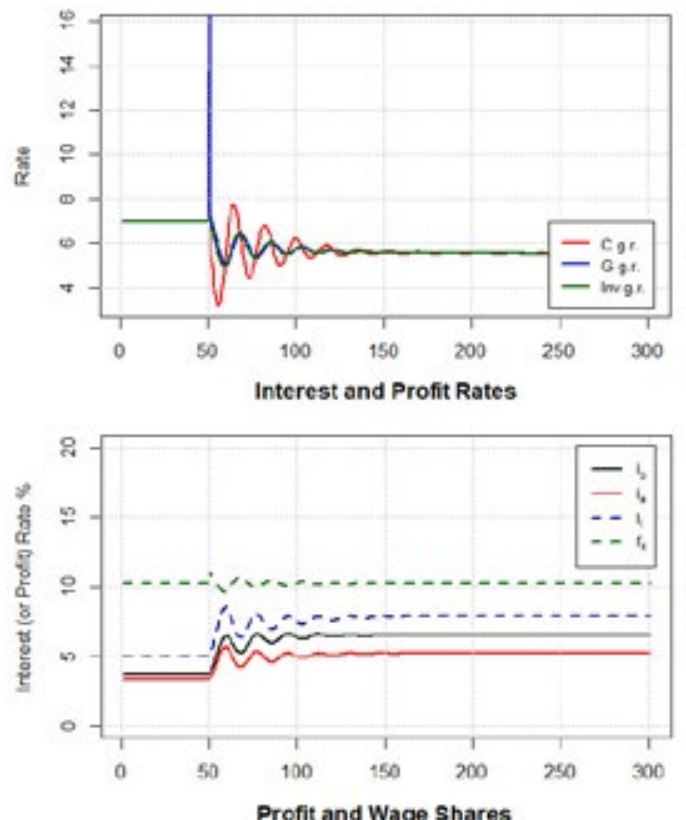

Profit and Wage Shares
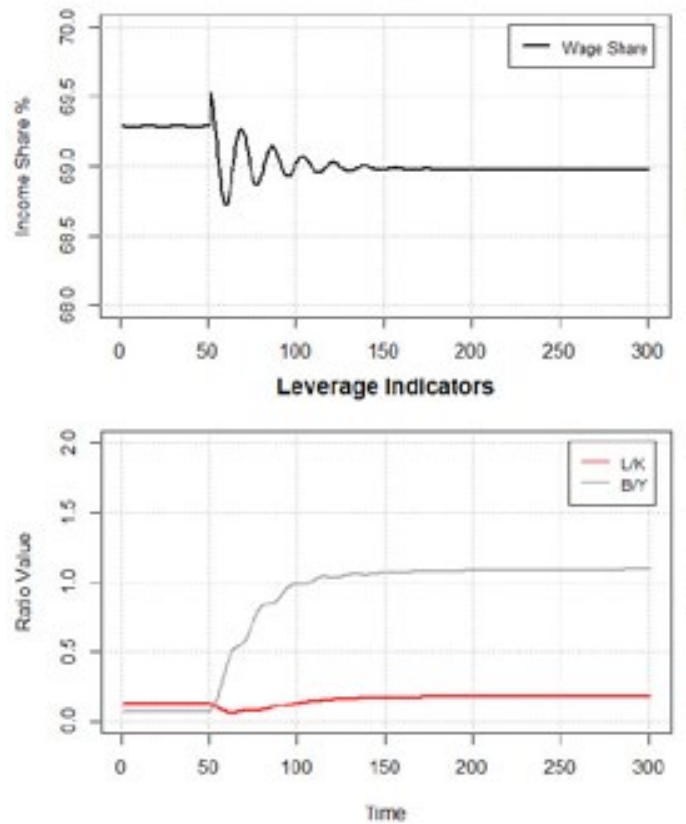

Capacity Utilization
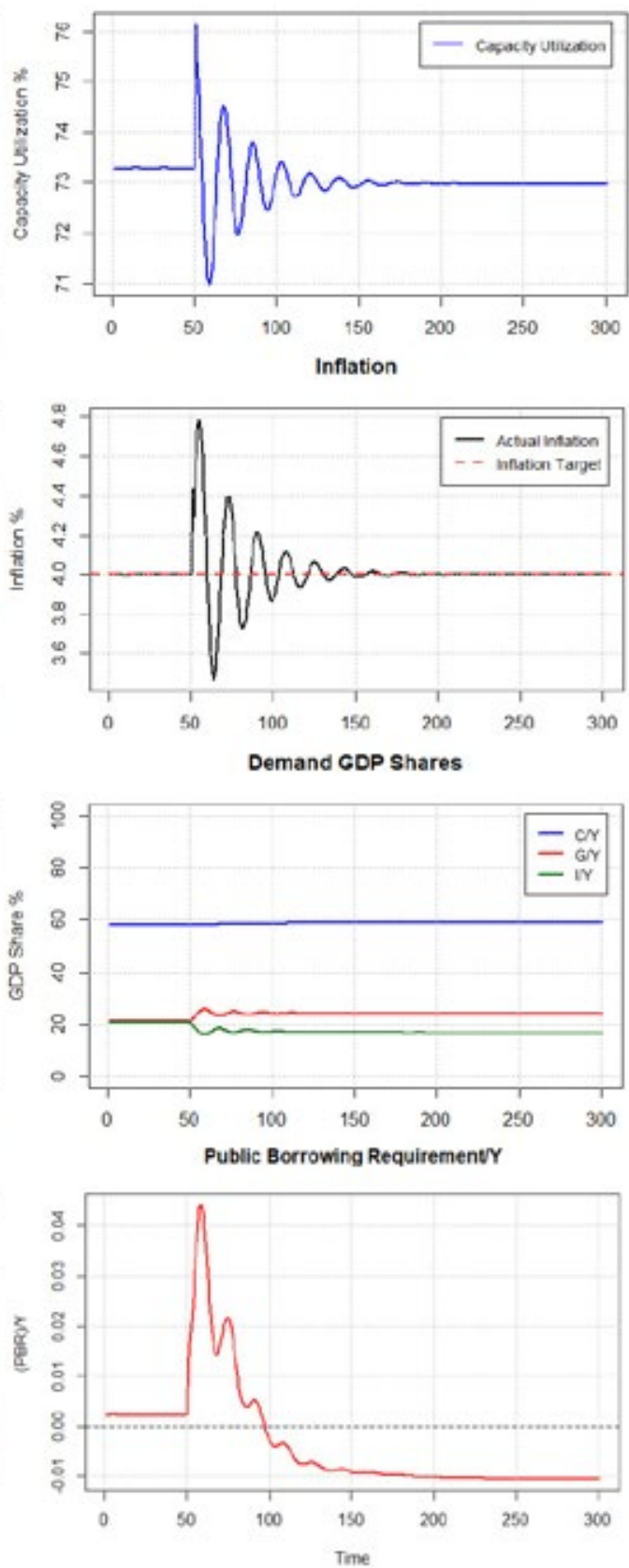

Figure 5 - Increase of Desired Ratio of Government Consumption to Capital Stock, $g_{0}$.

\section{FINAL REMARKS}

Throughout this article we developed a SFC growth model that aims to understand the dynamics of public financing and its interrelations with the other macroeconomic variables in a closed economy with government activities, in which 
monetary policy is conducted under an Inflation Targeting Regime, there is no money financing of government debt and government issues an interest rate-indexed bond in order to finance its fiscal deficit. As general features of the model, we have (i) a Taylor rule to define the short-term interest rate; (ii) a long-rate determined by the balance between the composition of financial wealth between government bonds and deposits, in one hand, and the portfolio decisions of households, on the other hand; and (iii) the dynamics of inflation being given by a inertial component and distributive conflict.

The complete model is characterized as a system of thirty-two difference equations, twenty-one parameters, two exogenous variables, and four initial stocks.

The results of the parameter mapping algorithm show that through the specification of the investment function of the model it is possible to obtain both led and profit led schemes according to Blecker (2002). Using the results plotted in figure 1 , when broadly mapped ${ }^{26}$, the most likely regime is wage led, with about $70 \%$ of the stable cases found.

Thus, in the presentation of the model, some simulations were carried out for a specific set of parameters that generated a wage led regime. The results of the simulation show that in an SFC growth model with inflation targeting and zero money financing of fiscal deficit, a permanent increase in the level of government expenditures produces a crowding-out effect over investment expenditures.

Following our model specification, in the presence of the Taylor rule of a single aim, expansionary fiscal policy is unable to accelerate economic growth. Permanent expansionary shocks cause a raise in short interest rate, which also causes an increase in the interest on loans and removes investment expenditures from the economy, since the profit rate remain almost the same. This is the accommodating mechanism for increasing public spending that generates crowding-out.

This is a novel and surprising result for the SFC model literature. Future research will investigate if these results could be also obtained in models with alternative Institutional Arrangements for fiscal and monetary policy.

As we had said before, the model presented here is by no means directly applied to any advanced or developing economy; so, the policy prescriptions should be taken with extremely care. The idea here was simply to analyze the implications of some stylized facts about the Institutional Arrangements of fiscal and monetary policy over the dynamics of an artificial economy. Trying to apply these policy advices to any real-world economy will be a clear example of the "Ricardian vice".

$26 \quad 10^{9}$ numerical simulations. 


\section{REFERENCES}

AMADEO, E.J. (1989). Keynes's Principle of Effective Demand. Aldershot: Edward Elgar. 1989.

ASIMAKOPOULOS, A. Keynes's General Theory and Accumulation. Cambridge: Cambridge University Press. 1991.

BLANCHARD, O; FISCHER, S. Lectures on Macroeconomics. Cambridge (Mass.): MIT Press. 1989.

BLECKER, R. A. "Distribution, Demand and Growth in Neo-Kaleckian Macro Models" In MARK SETTERFIELD (ed.), Demand-Led Growth: Challenging the Supply-Side Vision of the Long Run, Northhampton MA: Edward Elgar. 2002.

CARVALHO, F.C. Liquidity preference and monetary economies. London: Routledge. 2015.

CALVO, G. A. "Staggered prices in a utility maximizing framework". Journal of Monetary Economics, v. 12, n. 3, p. 383-398. 1983.

CARLIN, W; SOSKICE, D. Macroeconomics: imperfections, institutions and policies. Oxford University Press: Oxford. 2006.

CHRISTOPHER, J.; RAMEY, A. V. "The Cyclical Behavior of the Price-Cost Markup". NBER Working Paper No 19099. 2013.

COSTA SANTOS, J. F. "Ensaios sobre Crescimento, Restrição ao Balanço de Pagamentos e Distribuição de Renda em Abordagem Stock-Flow Consistent (SFC). (Phd Thesis Retrieved from https://repositorio.ufu.br/handle/123456789/20702). 2017.

DOS SANTOS, C. H.; ZEZZA, G. "A simplified, 'Benchmark', Stock-Flow Consistent Post-Keynesian Growth Model”. Metroeconomica. v.59, n.3; p.441-478, 2008.

FABOZZI, F. Equity Portfolio Management. New York: Wiley \& Sons. 1999.

GREENWOOD-NIMMO, M. Inflation targeting monetary and fiscal policies in a two-country stock-flow-consistent model. Cambridge Journal of Economics, v. 38, n. 4, p. 839-867, 2013.

GODLEY, W. "Money and credit in a Keynesian model of income determination". Cambridge Journal of Economics, v. 23, n. 4, p. 393-411, 1999.

GODLEY, W.; LAVOIE, M. "Fiscal policy in a stock-flow consistent (SFC) model". Journal of Post Keynesian Economics, v. 30, n.1, p. 79-100, 2007a.

Monetary economics: an integrated approach to credit, money, income, production and wealth. 1a ed. Nova York: Palgrave Macmillan, 2007b.

HARCOURT, G. The Structure of Post-Keynesian Economics. Cambridge: Cambridge University Press. 2006. 
HEIN, E. The Macroeconomics of Finance-dominated Capitalism - and its Crisis. Edward Elgar Publishing Limited. Massachusetts. 2012.

HOLANDA BARBOSA, F. "The contagion effect of public debt on monetary policy: the Brazilian experience". Brazilian Journal of Political Economy, Vol. 26, N.2. 2006.

Kaldor, N. "The role of effective demand in the short run and in the long run" In: Barrère, A. (Org.). The Foundations of Keynesian Analysis. London: Macmillan. 1988.

KINSELLA, S.; O'SHEA, T. "Solution and Simulation of Large Stock Flow Consistent Monetary Production Models via Gauss Seidel Algorithm". Journal of Policy Modeling. 2017.

LAVOIE, M.; GODLEY, W. "Kaleckian Models of Growth in a Coherent Stock-Flow Monetary Framework: A Kaldorian View". Journal of Post Keynesian Economics, v. 24, n. 2, p. 277-311, 2001.

"Kaleckian models of growth in a coherent stock-flow monetary framework: a Kaldorian view". Journal of Post Keynesian Economics, v. 24, n. 2, p. 277-311, 2011.

LAVOIE, M. Endogenous money: accommodationist. In: ARESTIS, P.; SAWYER, M. (Ed.). A handbook of alternative monetary economics. Cheltenham: Edward Elgar, p. 17-34. 2006.

. "Modern monetary theory and post-keynesian economics". Real-world economics review, Issue no.89, 2019.

LE HERON, E.; MOUAKIL, T. A Post-Keynesian Stock-Flow Consistent Model for Dynamic Analysis of Monetary Policy Shock on Banking Behaviour. Metroeconomica, 59(3), p. 405-440, 2008.

LEWIS, A. "Economic Development with Unlimited Supply of Labor". The Mancheser School, Vol. 22, pp. 139-191. 1954.

LIMA, G. T.; SETTERFIELD, M. "Inflation Targeting and Macroeconomic Stability in a Post Keynesian Economy." Journal of Post Keynesian Economics, v. 30, p. 435-461, 2008.

MACEDO E SILVA, A. C.; DOS SANTOS, C. H. Peering over the edge of the short period? The Keynesian roots of stock-flow consistent macroeconomic models. Cambridge Journal of Economics. v. 34, p. 105-124, 2011.

MARGLIN, S. A., BHADURI, A. Profit Squeeze and Keynesian Theory, In Marglin, S. A. \& Schor, J. B. (eds.) The Golden Age of Capitalism, Oxford University Press. 1990. 
NEKARDA, C. J.; RAMEY, V. A. "The cyclical Behavior of the Price-cost Markup", Working paper, 2013.

OREIRO, J. L. C.; ROCHA, M. A. "Inflation Targeting Regimes, Institutional Flexibility and Growth Performance: A Keynesian/Kaldorian Perspective in a Dynamic Panel Analysis". Análise Econômica (UFRGS), v. 29, p. 61-93, 2011.

O'SHEA, T.; KINSELLA, S. "Solution and Simulation of Large Stock Flow Consistent Monetary Production Models via the Gauss Seidel Algorithm”. Working paper. 2016.

ROBINSON, J. The Accumulation of Capital. London: Macmillan. 1956.

ROCHON, L.P. "The State of Post Keynesian Interest Rate Policy: Where are we and where are we going?". Journal of Post Keynesian Economics. v.30(1), p. 3-11. 2007.

ROWTHORN, R. Conflict, Inflation and Money. Cambridge Journal of Economics, v. 1. p. 215-239, 1977.

Demand, real wages and economic growth, Thames Papers in Political Economy, Autumn: pp.1-39, 1981.

SETTERFIELD, M. "Is Inflation Targeting Compatible with Post Keynesian Economics?" Journal of Post Keynesian Economics, v.28, p.653-71, 2006.

Schumpeter, J. A. History of Economic Analysis, edited by Elisabeth Boody Schumpeter. New York: Oxford University Press, 1954.

SILVEIRA, A.M. "The Ricardian vice and the indetermination of Senior". Ensaios Econômicos FGV EPGE, N.205, 1992.

SMITHIN, J. The theory of interest rates. In: ARESTIS, P.; SAWYER, M. (Ed.). A handbook of alternative monetary economics. Cheltenham: Edward Elgar, $p$. 273-290. 2006.

TAYLOR, J. B. "Discretion versus policy rules in practice". Carnegie-Rochester Conference Series on Public Policy, p. 195-214, Dec. 1993.

TINBERGEN, J. Economic Policy: Principles and Design. North-Holland Publishing Company Amsterdam. 1956.

TOBIN, J. Asset accumulation and economic activity. Chicago: University of Chicago Press, 1980.

Money and finance in macroeconomic process. Journal of Money, Credit and Banking, v. 14, n. 2, p. 171-204, 1982.

TREECK, T. "A synthetic stock-flow consistent macroeconomic model of 'financialization'. Cambridge Journal of Economics, Vol. 33, n.3. 2009.

ZEZZA. G.; DOS SANTOS, C. H. Distribution and growth in post-Keynesian stock- 
flow consistent model. In Salvadori, N. (ed.): Economic Growth and Distribution. On the Nature and Causes of Wealth of Nations. Edward Elgar, Cheltenham. 2006.

\section{APPENDIX}

1. Determination of the interest rate over interest rate-indexed government bonds, $i_{b}$ :

Using Market clearing condition, we must have $B^{s}=B^{d}$. Thus, using (13), (17) and (18), we have:

$$
\begin{aligned}
& {\left[\lambda_{0}+\lambda_{1} \cdot\left(i_{b}-i_{a}\right)\right] \cdot V_{r_{-1}}-\lambda_{2} \cdot(1-\theta) \cdot Y=\left(1+i_{b_{-1}}\right) B_{-1}^{s}+G-\left(T+F_{c b}\right)} \\
& \text { Making }{ }^{i} \text { the endogenous variable, we have: }
\end{aligned}
$$

$\lambda_{1} \cdot i_{b} \cdot V_{r_{-1}}=-\lambda_{0} \cdot V_{r_{-1}}+\left(1+i_{b-1}\right) B_{-1}^{s}+G-\left(T+F_{c b}\right)+\lambda_{2} \cdot(1-\theta) \cdot Y+\lambda_{1} \cdot i_{a} \cdot V_{r_{-1}}$

Isolating $i_{b}$ :

$$
i_{b}=-\frac{\lambda_{0}}{\lambda_{1}}+\frac{\left(1+i_{b-1}\right) B_{-1}^{S}+G-\left(T+F_{c b}\right)+\lambda_{2} \cdot(1-\theta) \cdot Y}{\lambda_{1} \cdot V_{r_{-1}}}+i_{a}
$$

Knowing that: $T=\theta . Y ; G=g_{0} . K_{-1} ; F_{c b}=i_{a_{-1}} \cdot A_{-1} ; A \equiv L-(1-\tau) . D$ ; $D \equiv V r-B$ and making all substitutions and algebric manipulation, we finally have:

$i_{b}=-\frac{\lambda_{0}}{\lambda_{1}}+i_{a}+\frac{(1-\tau)}{\lambda_{1}} \cdot i_{a_{-1}}+\frac{\left(1+i_{b_{-1}}\right) B_{-1}^{S}+g_{0} \cdot K_{-1}-i_{a_{-1}} \cdot\left(L_{-1}+(1-\tau) \cdot B_{-1}\right)+\left[\lambda_{2} \cdot(1-\theta)-\theta\right] \cdot Y}{\lambda_{1} \cdot V_{r_{-1}}}$ 